\title{
Cerebral malaria: why experimental murine models are required to understand the pathogenesis of disease
}

\author{
J. BRIAN DE SOUZA ${ }^{1,2}$, JULIUS C. R. HAFALLA ${ }^{1}$, ELEANOR M. RILEY $^{1}$ \\ and $\mathrm{KEVIN}$ N. COUPER ${ }^{1 *}$ \\ ${ }^{1}$ Immunology Unit, Department of Infectious and Tropical Diseases, London School of Hygiene and Tropical Medicine, \\ Keppel Street, London WC1E 7HT, UK \\ ${ }^{2}$ Department of Immunology and Molecular Pathology, University College London Medical School, 46 Cleveland Street, \\ London W1T $4 \mathcal{F F}, U K$
}

(Received 14 September 2009; revised 20 October 2009; accepted 26 October 2009; first published online 23 December 2009)

\begin{abstract}
S UMMAR Y
Cerebral malaria is a life-threatening complication of malaria infection. The pathogenesis of cerebral malaria is poorly defined and progress in understanding the condition is severely hampered by the inability to study in detail, ante-mortem, the parasitological and immunological events within the brain that lead to the onset of clinical symptoms. Experimental murine models have been used to investigate the sequence of events that lead to cerebral malaria, but there is significant debate on the merits of these models and whether their study is relevant to human disease. Here we review the current understanding of the parasitological and immunological events leading to human and experimental cerebral malaria, and explain why we believe that studies with experimental models of CM are crucial to define the pathogenesis of the condition.
\end{abstract}

Key words: cerebral malaria, murine model, pathogenesis.

\section{INTRODUCTION}

Malaria remains a major public health problem in many tropical countries. The World Health Organization (WHO) estimates that $40 \%$ of the world's population lives in areas affected by malaria, resulting in approximately 200-300 million clinical cases each year, leading to the deaths of more than 2 million young children every year, mainly in subSaharan Africa. The vast majority of cases of severe malaria are caused by infection with the Plasmodium falciparum species of the parasite. Clinical presentations of severe malaria vary but include altered consciousness, respiratory distress, severe anaemia (haemoglobin level of $<5 \mathrm{~g} / \mathrm{dl}$ ), multi-organ failure and cerebral malaria. The WHO definition of CM is unrousable coma (graded according to either Blantyre or Glasgow coma scale) not attributable to other causes (Teasdale and Jennet, 1974; Molyneux et al. 1989). In areas of high malaria transmission, susceptibility to severe malaria varies with age and exposure to the parasite; adults are, in general,

* Corresponding author: Immunology Unit, Department of Infectious and Tropical Diseases, London School of Hygiene and Tropical Medicine, Keppel Street, London WC1E 7HT, UK. Tel: +44207927 2690. Fax: +44207927 2807. E-mail : kevin.couper@1shtm.ac.uk resistant to severe malaria whilst infants and very young children are at significantly increased risk of developing severe malarial anaemia. Older children, who have had at least one previous malaria infection, are disproportionately at risk of developing cerebral malaria (CM) (Marsh and Snow, 1999). The epidemiology of severe malaria is highly suggestive of a role for the immune system in both initiation of (in children) and protection from (in adults) cerebral malaria, either indirectly - by selecting for infection by parasites of differing virulence - or directly - by contributing to the pathogenesis of the syndrome.

CEREBRAL MALARIA

The incidence of cerebral malaria is difficult to assess, but hospital admission records indicate that in the region of $1 \%$ of all $P$. falciparum infections progress to CM, which is fatal in $10-20 \%$ of all cases (300000-500000 deaths each year). Moreover, at least $10-20 \%$ of individuals who survive and recover from CM display long-term physical or cognitive dysfunction (Carter et al. $2005 a$, b; Idro et al. 2005; Boivin et al. 2007). Since the discovery by Marchiafava and Bignami in 1894 of malaria parasites within the brain of humans during infection, attention has focussed on understanding the pathophysiological processes that predispose towards 
CM, with a view to the development of preventative measures or targeted therapies for the condition. Contrasting theories on the roles of parasite sequestration within the brain and the host immune response to the parasite in the pathogenesis of CM were initially proposed (reviewed by Van der Heyde et al. 2006), with current understanding suggesting that neuropathology is the result of a combination of both processes, as discussed below.

Cerebral malaria can develop rapidly after initial bouts of fever lasting 2-3 days. Coma is the standard definition of CM, but other symptoms associated with the condition include general malaise, headache, fits, vomiting and diarrhoea. The clinical symptoms associated with early-stage CM are not pathognomonic for the condition and are difficult to differentiate from encephalitis, meningitis and febrile convulsions. This has implications for the rapid and early diagnosis of the condition, which often significantly delays the initiation of treatment. The early symptoms of CM can progress rapidly to increased intracranial pressure, hemiparesis, ataxia and coma if immediate medical treatment is not provided. The diverse set of neurological complications associated with $\mathrm{CM}$ indicates that multiple areas of the brain are affected by the condition.

Anti-malarial drug-based therapies are the firstline treatment for patients with cerebral malaria; however, the incidence of neurological deficiencies and mortality remain unacceptably high with fatality rates of around $15 \%$ following treatment with Artemisinin compared with $20 \%$ for traditionally used quinine-based treatments (Dondorp et al. $2005 a$ ). This is unsurprising as anti-malarial therapy can only be implemented when CM is first suspected or diagnosed at health care centres; CM is at an advanced state in the majority of these individuals and anti-malarial drugs by themselves are often insufficient to reverse and alleviate the symptoms of CM. Therefore, there is an urgent need to develop adjunctive therapies, such as immuno-modulators or neuro-protective agents that may be administered with anti-malarials. At present the lack of understanding of the pathogenesis of CM means that the potentially most efficacious targets for therapeutic intervention remain to be identified.

THE PATHOLOGY AND ASSOCIATED CLINICAL FEATURES OF CM

Post-mortem examinations of brains from individuals that succumbed to CM have helped to uncover the type and distribution of brain pathology that occurs during the condition. Some of the most commonly reported findings include swelling and haemorrhaging in the white matter of the subcortical rim and corpus callosum as well as petechial and ring haemorrhages in both cerebral and cerebellar cortices (reviewed by Haldar et al. 2007). In the majority of cases, histopathological examinations reveal cerebral capillaries plugged with parasitized erythrocytes (reviewed by Haldar et al. 2007). Margination of monocytes and macrophages within cerebral vessels and the presence of pigmented macrophages sequestered with $\mathrm{pRBC}$ are also well described features of CM (Patnaik et al. 1994). Due to the lack of detailed comparative histopathological studies of pediatric and adult CM cases it is difficult to conclude whether the pathology of CM varies between children and non-immune adults, but as there are a number of differences in the symptoms of pediatric and adult CM, it is possible there may be some age-related differences in cerebral pathology (Mishra and Wiese, 2009).

Although parasite sequestration, haemorrhages and inflammation are found in the majority of CM brains, it is clear that CM is not a homogenous syndrome. For example, 3 different patterns of histopathological changes have been described in African children: in addition to the 'classical' pattern of CM of parasite sequestration, perivascular haemorrhages and immune cell infiltration within brain micro-vessels, parasite sequestration may be observed within the brain in the absence of any other abnormalities and there are cases where individuals with high peripheral parasitaemia develop a syndrome that is clinically defined as CM but where there is no evidence of parasite sequestration within the brain (Clark et al. 2003; Taylor et al. 2004). The reasons for the variations in pathology of $\mathrm{CM}$ are unclear but may be due to genetic variation in hosts or parasites, environmental factors or the host immune response to the parasite.

\section{THE LIMITATIONS OF STUDIES OF HUMAN CEREBRAL MALARIA IN DEFINING THE PATHOGENESIS OF THE CONDITION}

Cerebral malaria is likely the result of a complex sequence of inter-related events, most probably beginning either with sequestration of trophozoiteinfected red blood cells (pRBC) in the small blood vessels (reviewed by Chakrovorty et al. 2008) and/or with the rupture of infected red blood cells and the release of parasite-derived toxins (Bate and Kwiatkowski, 1994; Schofield et al. 1996). The relative importance of systemic versus brain-localized events - including $\mathrm{pRBC}$ sequestration and rupture, lymphocyte, monocyte, endothelial and glial cell activation and release of inflammatory mediators their sequence and timing in the pathogenesis of CM are very much unknown. For obvious reasons, histopathological examination of CM brains is limited to post-mortem analysis of fatal cases and it is thus not possible to describe the sequence of events leading to the onset of CM symptoms nor to compare fatal cases with those that resolve in response to treatment. Such investigations and comparisons are 
essential to delineate truly pathogenic systemic and intra-cerebral processes from neutral and/or protective responses. Increased utility of non-invasive in vivo imaging techniques, such as magnetic resonance imaging (MRI) and spectroscopy (MRS) and computational topography (CT), should hopefully help to address these issues (Kampfl et al. 1993; Crawley et al. 1996; Patanker et al. 2002; Penet et al. 2005, 2007), but these studies are severely restricted by ethical constraints and the availability of the expensive specialized equipment in malaria-endemic areas. It is therefore extremely difficult to move beyond purely descriptive and correlative studies in humans: defining the immunological pathways and parasite-driven processes that underlie the pathogenesis of the syndrome, and demonstrating causality, is difficult without direct intervention studies. Moreover, examination of peripheral blood (which is possible in non-fatal as well as fatal cases) may provide limited information on the immunological and parasitological environment in the brain and, again, patients usually present to hospital only once the syndrome is well-established. For example, peripheral blood parasitaemia does not always accurately predict total parasite biomass (Silamut et al. 1999) and total parasite biomass is a stronger correlate of severe malarial disease than is peripheral parasitaemia (Dondorp et al. 2005 b). It is clear that other approaches - in combination with human studies are required to fully understand the pathogenesis of CM.

EXPERIMENTAL MODELS OF CEREBRAL MALARIA

Much of our understanding of mammalian physiology has come from studies of animals and the extent of the conservation of basic immunological and neuropathological processes between laboratory rodents and humans is becoming ever more apparent (Hau and Van Hoosier Jr, 2005). Experimental models have proven invaluable for understanding the pathogenesis of numerous autoimmune and infectious diseases of humans and many vaccines and immune-therapies currently in use were initially developed and tested in experimental models (Hau and Van Hoosier Jr, 2005). It is likely, therefore, that the use of relevant experimental animal models can significantly aid in the study of cerebral malaria. Primate models of CM, including P. knowlesi and $P$. coatneyi infections in Rhesus monkeys (Aikawa et al. 1992; Ibiwoye et al. 1993) and P. falciparum infection in squirrel monkeys (Gysin et al. 1992), have allowed the investigation of some aspects of CM, but these models are prohibitively expensive and are restricted to low numbers for ethical reasons. Consequently, other experimental models are required. Neuropathological syndromes have been shown to develop in certain strains of inbred mice infected with various strains of Plasmodium berghei
(Pb) (Rest, 1982; Curfs et al. 1993a) or the lethal (XL) variant of P. yoelii (PyXL) (Yoeli and Hargreaves, 1974); however, there has been - and continues to be - significant disagreement within the malaria research community as to whether the murine models share sufficient similarities with human cerebral malaria to make them relevant or useful. In the remainder of this review we will evaluate the currently available models of ECM and we will attempt to resolve the relevance of experimental models of cerebral malaria to human infection.

\section{Plasmodium yoelii XL and Plasmodium berghei $K 173$}

Although more extensively studied as a model of hyperparasitaemia and failure of parasite control (Couper et al. 2007, 2008), PyXL has been shown to sequester within the brain microvasculature and produce a cerebral syndrome comparable with human cerebral malaria (Yoeli and Hargreaves, 1974; Kaul et al. 1994); however, the hyper-parasitaemia associated with this infection (rapidly ascending peripheral parasitaemia that can reach $80-100 \%$ ) is not typical of human CM cases (Silamut et al. 1999) and this model is not widely used to study CM. In a few studies, $P$. berghei $\mathrm{K} 173$ has been found to induce CM-like signs (Curfs et al. 1993 a; Mitchell et al. 2005), but the dose-dependent onset of ECM in this model (inducing cerebral pathology after low dose but not high dose infection) (Mitchell et al. 2005) also limits its utility as a model of human CM : indeed P. berghei K173 is frequently used as a nonECM-infection to compare with the most widely used model of ECM, P. berghei ANKA infection (Mitchell et al. 2005).

\section{Plasmodium berghei $A N K A$}

The Plasmodium berghei ANKA (PbA) model replicates many events seen during human CM and is accepted as the best available experimental model of cerebral malaria. Infection of susceptible strains of mice, including C57BL/6 and CBA, leads to the development of fatal cerebral pathology, with clinical signs including ataxia, fitting, respiratory distress and coma (de Souza and Riley, 2002). The time to onset of clinical signs varies depending on the infection dose, the genetic background of the host and the specific clone of infecting parasites, but is typically between 5 and10 days post-infection (de Souza and Riley, 2002). As in humans, there is a rapid deterioration in the condition of infected animals once clinical signs become apparent, with death often occurring within 4 or $5 \mathrm{~h}$ after the onset of neurological signs. Multiple areas of blood-brain barrier disruption with vascular leakage involving the cortex, cerebellum and olfactory bulb are observed in brains of $\mathrm{PbA}$-infected mice displaying signs of ECM 


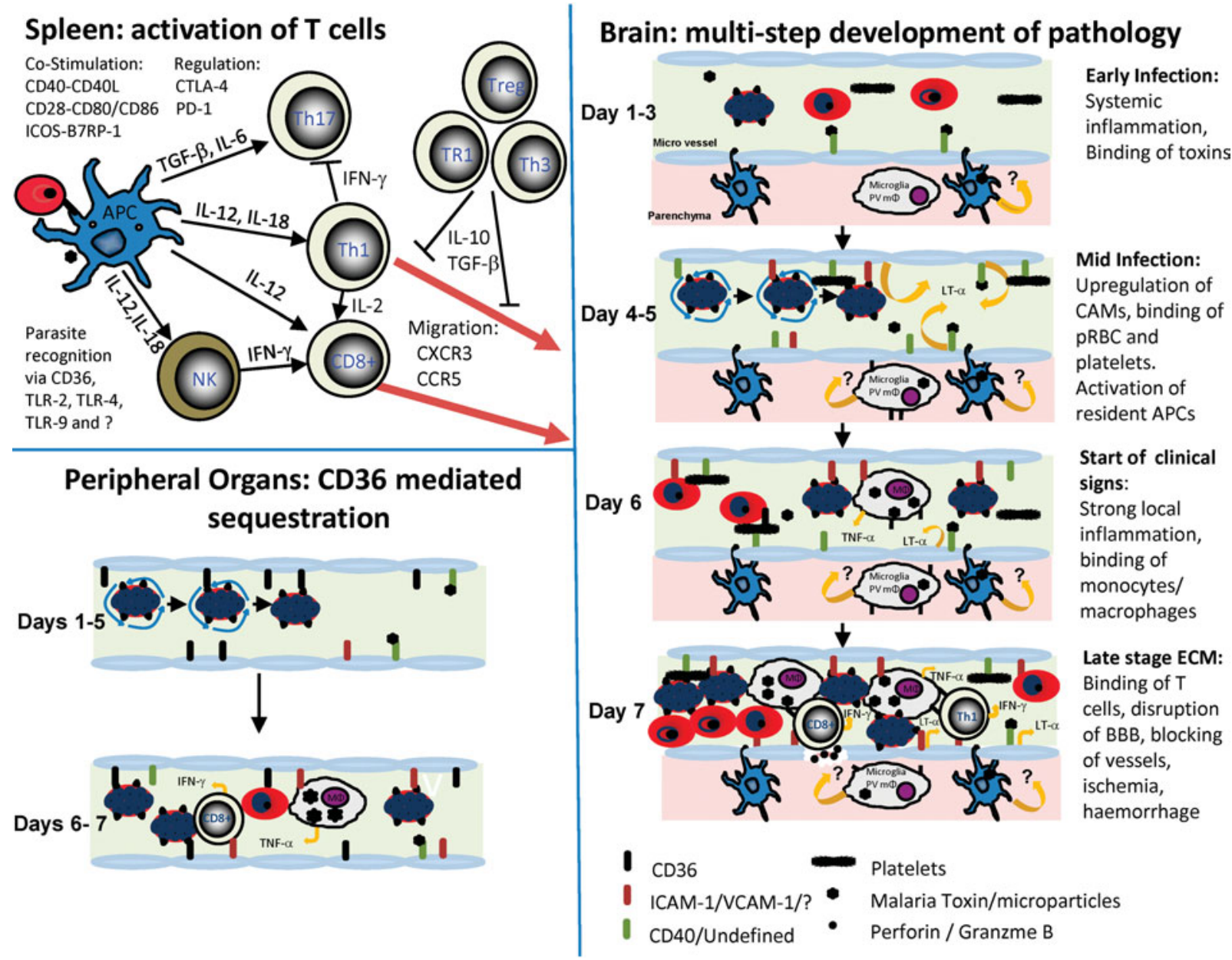

Fig. 1. A hypothetical schema of events leading to the development of experimental cerebral malaria. Rupture of pRBCs releases molecules that activate brain microvascular endothelial cells leading to upregulation of receptors for pRBC. Phagocytosis of parasite moieties in the spleen and liver, priming lymphocytes within the spleen, promotes systemic inflammation which further amplifies endothelial cell activation in the brain and activates brain-resident perivascular macrophages, microglia and astrocytes. pRBCs bind to endothelial receptors; platelets binding to endothelial receptors may provide additional ligands for $\mathrm{pRBC}$ adherence. Activated endothelial and glial cells provide chemotactic signals for lymphocytes and myeloid cells. Sequestered pRBCs and leukocytes interfere with cerebral blood flow and, together with cytotoxic molecules, damage the blood-brain barrier leading to oedema and haemorrhage.

(Penet et al. 2005; Lackner et al. 2006; de Souza and Couper, unpublished observations), with loss of specific neuronal populations within the cortex and striatum (Clark et al. 2005), accumulation of pRBC within blood vessels (Rest, 1982; Hearn et al. 2000) and focal perivascular inflammation (Engwerda et al. 2002). ECM is also associated with the significant accumulation of platelets within the brain vasculature (Wassmer et al. 2003; von Zur Muhlen et al. 2008): platelets have been shown to directly promote endothelial cell damage during infection (Wassmer et al. 2006). Cognitive dysfunction during P. berghei ANKA infection, as shown by impaired visual memory, is directly correlated with haemorrhage and inflammation, including microglial activation (Desuisseaux et al. 2008). Indeed, accumulation of monocytes and macrophages, and activation of brain resident mononuclear cells, including astrocytes and microglial cells is believed to be a key feature of
ECM (Grau et al. 1987; Medana et al. $1997 a, b$; Pais and Chatterjee, 2005) (Fig. 1).

As in humans, genetic and environmental factors determine the susceptibility of mice to ECM. For example, the resistance of $\mathrm{F} 1$ intercrossed $\mathrm{BALB} / \mathrm{c}$ (resistant) and $\mathrm{C} 57 \mathrm{BL} / 6$ (susceptible) mice to the development of ECM is determined by age, and environmental exposure, with young mice (8-10 weeks) susceptible to ECM and older mice (16-20 weeks) resistant to the development of cerebral signs (Hearn et al. 2000). Genetic resistance to ECM and $P$. berghei ANKA infection has been mapped using intercrossed resistant and susceptible strains of mice to loci on chromosomes 1, 9, 11, 17 and 18 (Bagot et al. 2002; Nagayasu et al. 2002; Ohno and Nishimura, 2004; Campino et al. 2005). However, the genes encoded within each of these regions that control resistance to ECM and parasite levels remain to be identified. More recently, micro-array profiling 
of susceptible and resistant strains of mice have identified distinct expression profiles in the brain of genes involved in metabolic energy pathways, immune-activation, apoptosis and neuroprotection/ neurotoxicity (Delahaye et al. 2007; Lovegrove et al. 2007; Oakley et al. 2008). Differences in the immune response of ECM-susceptible and ECM-resistant strains of mice to infection are discussed in more detail below.

THE ROLE OF PARASITE SEQUESTRATION DURING HUMAN AND EXPERIMENTAL CEREBRAL MA LAR I A

The sequestration of mature parasites within peripheral tissues via adherence of $\mathrm{pRBC}$ to vascular endothelium is a common feature of malaria infections. It is believed that this prevents the clearance of mature-stage parasites by the spleen, allowing the development of sufficient numbers of infectious parasites (gametocytes) to ensure transmission to mosquitoes (Beeson et al. 2001; Engwerda et al. 2005). Although sequestration is initially beneficial to the parasite, it is widely believed to have significant deleterious consequences for the host. For many years it was assumed that the symptoms of CM were due solely to occlusion of brain microvessels by sequestered pRBC (reviewed by Berendt et al. 1994; Van der Heyde et al. 2006). In this scenario, parasite adherence to brain endothelial cells, combined with rosetting of uninfected and infected red blood cells, impairs blood flow leading to hypoxia, hypoglycaemia and the buildup of toxic waste products, including lactic acid (Van der Heyde et al. 2006), which rapidly leads to irreversible tissue damage. However, the typically quite subtle neurological consequences experienced by CM survivors are not consistent with this simple aetiology and other causes of disrupted neuronal signalling are also likely to play a part (Rae et al. 2004; Penet et al. 2005; Hunt et al. 2006).

Although parasite sequestration is usually seen in CM brains, the association is not absolute and, despite a plethora of associative data, there is very little empirical evidence that parasite sequestration in the brain is either necessary or sufficient to cause CM. Deaths attributable to CM, as defined by WHO guidelines, have been observed in the absence of parasite sequestration within the brain (Clark et al. 2003; Taylor et al. 2004; Haldar et al. 2007). Furthermore, parasite sequestration has been observed in individuals that did not develop severe cerebral malaria (Silamut et al. 1999; Seydel et al. 2006). This heterogeneous association between cerebral parasite sequestration and clinical outcome raises important questions regarding the precise aetiology of CM (Clark et al. 2006). Specifically, we need to consider the possibility that transient interactions between sequestering $\mathrm{pRBC}$ and cerebral tissues might be sufficient to trigger downstream immunological and biochemical processes that lead to the development of CM.

The widespread assumption that sustained parasite sequestration in the brain is essential for development of CM has led some researchers to question whether cerebral parasite sequestration occurs during $P$. berghei ANKA infection and thus whether the pathogenesis of ECM is comparable to human CM (Berendt et al. 1994; Franke-Fayard et al. 2005). Accumulation of PbA pRBCs in cerebral and cerebellar capillaries of mice displaying signs of ECM has been observed at both light and electron microscopic levels (Rest, 1982; Jennings et al. 1998; Hearn et al. 2000; Beghdadi et al. 2008). Detailed investigations on the nature of parasite sequestration during $P$. berghei ANKA infection have, however, yet to be performed and as such it is unknown whether $\mathrm{PbA}$ parasites adhere through strong, tight junctions, or via weak easily disrupted interactions. The comparison of parasite sequestration in the brain during ECM and CM is also severely complicated by the method of tissue preparation; mouse brains are routinely perfused prior to histological examination during ECM, but perfusion is seldom performed prior to the examination of brains from individuals with fatal CM. As such, parasite sequestration may be frequently under-estimated (in ECM) or over-estimated (in CM). Nevertheless, most blocked vessels during ECM contain a mixture of parasitized RBC and leukocytes (Hearn et al. 2000; Jennings et al. 1998). Consequently, parasite accumulation alone may not be sufficient to cause blockage of brain-micro-vessels during $P$. berghei ANKA infection.

Recently, Franke-Fayard et al. (2005) reported CD36 (Scavenger type B receptor)-mediated sequestration of luciferase-expressing P. berghei ANKA pRBC, visualized by bioluminescent imaging, in lung and adipose tissue but not in the brains of infected mice. This is consistent with the requirement for CD36-mediated $\mathrm{PbA}$ pRBC sequestration for initiation of acute lung injury (Lovegrove et al. 2008), and with the observation that CD36 ${ }^{-/-}$mice are fully susceptible to ECM. These findings have been interpreted as evidence that $\mathrm{pRBC}$ sequestration does not occur in the brain during $\mathrm{PbA}$ infection and is not required for initiation of ECM, and thus that ECM has a significantly different aetiology to CM (Franke-Fayard et al. 2005). However, whole body imaging and multi-organ comparisons may under-estimate cerebral sequestration since it is likely that the density of sequestered $\mathrm{pRBC}$ is much lower in brain than in much more heavily vascularized organs such as lung or spleen, and higher resolution analysis of the brain is required to rule out sequestration; nevertheless, and despite the authors claims, focal parasite sequestration was evident in one of the two examples of day 
7 p.i. brains shown by Franke-Fayard et al. (2005). Secondly, the lack of a role for CD36 in ECM does not rule out that (as in humans) there are other receptors mediating $\mathrm{pRBC}$ sequestration in the brain (as discussed below). Importantly, other studies using the same bioluminescent parasite system have not only shown significant accumulation of $P$. berghei ANKA pRBC in the brains of mice showing signs of ECM, but have also demonstrated that parasite biomass in the brain is directly correlated with risk of ECM (Amante et al. 2007 ; Randall et al. $2008 a$; Nie et al. 2009).

HOST CELL RECEPTORS MEDIATING

CYTO-ADHERENCE DURING CM AND ECM

Although CD36 appears to be the main receptor for $P$. falciparum pRBC sequestration in peripheral organs, CD36-mediated adhesion is not believed to be involved in sequestration in the brain (Newbold et al. 1999); CD36 is expressed only at very low levels in healthy brain tissue and it is not upregulated during malaria infection (Turner et al. 1994; Newbold et al. 1999). Nonetheless, it has recently been postulated that platelets and platelet and endothelial cell derived microparticles - submicron particles generated by vesiculation of cellular membranes (reviewed by Coltel et al. 2006) - may bind to brain endothelial cells, providing a source of CD36 that allows indirect CD36-mediated pRBC binding to brain endothelial cells (Wassmer et al. 2004; Faille et al. 2009); however, this hypothesis remains to be validated in vivo.

At present, intercellular adhesion molecule 1 (ICAM-1) is the most studied putative endothelial receptor for the sequestration of $P$. falciparum $\mathrm{pRBC}$ within the brain (Newbold et al. 1999; Chakravorty and Craig, 2005). The expression of ICAM-1 is significantly upregulated on cerebral vasculature endothelium during malaria infection (Turner et al. 1994; Newbold et al. 1999), and P. falciparum $\mathrm{pRBC}$ bind to ICAM-1 in vitro under flow conditions (Ockenhouse et al. 1991, Udomsangpetch et al. 1996; Adams et al. 2000). Strains of P. falciparum differ in their ability to bind to ICAM-1 and CD36 (Johnson et al. 1993; Gardner et al. 1996; Udomsangpetch et al. 1996) and although there is some evidence that the degree of binding of pRBC to ICAM-1 is associated with risk of development of CM (Newbold et al. 1999), this correlation is not absolute (Rogerson et al. 1999; Heddini et al. 2001). Moreover, there are conflicting data on links between risk of CM and allelic variation in the ICAM-1 gene. Specifically, a non-synonomous single nucleotide polymorphism in ICAM-1 (ICAM-1 kilifi) has been shown to be either associated (Fernandez-Ryes et al. 1997), or not associated (Bellamy et al. 1998; Fry et al. 2008) with the risk of severe malaria. Consequently, it has been proposed that other receptors may facilitate
pRBC sequestration within the brain (Ockenhouse et al. 1992; Chakravorty and Craig 2005). Upregulated expression of VCAM-1, E-Selectin and ELAM-1 by brain microvascular endothelium is also observed during CM; however, as with ICAM-1, there is significant debate on the role of these receptors (Ockenhouse et al. 1992; Silamut et al. 1999; Udomsangpetch et al. 1996), which may reflect difficulties in comparing in vitro studies using platebound receptors or (non-cerebral) endothelial cells with what may occur in vivo during infection. The failure to identify a single critical receptor mediating pRBC sequestration in the brain during CM may indicate promiscuous or redundant receptor binding by the parasite. This fits the current model where $P$. falciparum cyto-adherence is a multi-step process involving multiple (possibly partially redundant) receptor interactions mediating primary contact, rolling and finally firm adhesion (Udomsangpetch et al. 1997; McCormick et al. 1997; Yipp et al. 2000; Gray et al. 2003; Ho et al. 1998).

As in human CM, ICAM-1, VCAM-1 and Pselectin are all upregulated on brain vascular endothelium in ECM-susceptible strains of mice during $P$. berghei ANKA infection (reviewed by Schofield and Grau, 2005; Good et al. 2005). Moreover, ICAM-1 deficient mice (backcrossed onto the susceptible C57BL/6 background) do not develop ECM, suggesting that ICAM-1 expression is an essential step in the pathway of development of ECM (Favre et al. 1999; Li et al. 2003). Leukocyte rolling in these mice was unimpaired - indicating that resistance to ECM was not due to decreased leukocyte sequestration in the brain - but $\mathrm{pRBC}$ sequestration within the brain was not specifically examined. Similarly, mice with specific defects in endothelial cell expression of $\mathrm{P}$-selectin are also resistant to ECM but, again, pRBC sequestration was not reported (Combes et al. 2004). Clearly, more detailed examinations of these mouse strains are required to determine whether ECM resistance is due to reduced $\mathrm{pRBC}$ sequestration, attenuation of immune responses (including suboptimal $\mathrm{T}$ cell activation) or both.

PARASITE LIGANDS MEDIATING pRBC

SEQUESTRATION DURING CEREBRAL MALARIA

Clonally variant surface antigens that are expressed on the surface of $P$. falciparum-infected erythrocytes are known to facilitate binding of $\mathrm{pRBC}$ to endothelial receptors (Newbold et al. 1999). The most studied of these is the $P$. falciparum erythrocyte membrane protein-1 (PfEMP-1) family of proteins. Encoded by var genes, PfEMP-1 is a polymorphic, high molecular weight $(200-500 \mathrm{kDa})$ protein comprised of variable numbers and sequences of duffy binding like (DBL) and cysteine-rich interdomain region (CIDR) domains that mediate binding to 
various host molecules (reviewed by Scherf, 2008). Infected erythrocytes from most $P$. falciparum isolates bind to CD36 through its interaction with CIDR-1 (Baruch et al. 1995, 1997). DBL-1 $\alpha$, with its clusters of glycosaminoglycan (GAG)-binding motifs, is believed to mediate the formation of rosettes (i.e. binding of infected erythrocytes to uninfected erythrocytes) (Chen et al. 1998), which have been linked to the pathogenesis of CM (Newbold et al. 1999), whereas DBL- $1 \beta$ binds to ICAM-1 (Smith et al. 2000; Oleinikov et al. 2009) and DBL $\gamma$ binds to chondroitin suphate A (CSA) (Reeder et al. 1999; Buffet et al. 1999; Gamain et al. 2004), the latter interaction mediating tissue-specific sequestration of $\mathrm{pRBC}$ in the placenta. Disease association studies have suggested that differences in CIDRs and DBLs between commonly expressed var genes may contribute to variations in parasite virulence (Jensen et al. 2004; Normark et al. 2007), such that some parasite isolates are more likely than others to sequester in particular tissues and therefore cause differing clinical presentations, but - with the exception of particular PfEMP-1 molecules that favour placental sequestration (Fried and Duffy, 2002; Salanti et al. 2004) - direct evidence to support this hypothesis is lacking. Moreover, the potential roles in $\mathrm{pRBC}$ sequestration of other parasite-encoded erythrocyte surface antigens such as stevors (subtelomeric variant open reading frame), rifins (repetitive interspersed family of genes), Pfmc-2TM, surfs (surface-associated interspersed genes), reticulocytehomologue binding proteins, EBA (erythrocyte binding antigen) and RhopH1/clag (high molecular mass rhoptry complex/ cytoadherence linked asexual gene) also need clarification (Scherf, 2008).

There are no known homologues of var genes in other malaria species. However, a large multi-gene Plasmodium interspersed repeat (pir) family has been identified in P. vivax (del Portillo et al. 2001) and is believed to be involved in antigenic variation. Homologues members of the pir family have been discovered in the rodent malaria parasites $P$. chabaudi (cir), P. yoelii (yir) and P. berghei (bir) (Carlton et al. 2002; Janssen et al. 2002; Cunningham et al. 2005). Whilst clonal antigenic variation has been described in P. chabaudi (McLean et al. 1986), the role of the cir family remains to be determined. Furthermore, whether the bir family plays a role in the development of $P$. berghei-induced ECM malaria remains to be elucidated.

THE ROLE OF THE IMMUNE RESPONSE IN THE PATHOGENESIS OF CEREBRAL MALARIA

\section{Human cerebral malaria}

The highly characteristic cytokine profiles that are associated with acute severe malaria provide associative evidence for involvement of the host immune response in the aetiology of CM. High plasma TNF, IFN- $\gamma$, IL-6 concentrations and elevated ratios of pro-to anti-inflammatory cytokines (including IL-10) are consistently observed in individuals with cerebral malaria when compared with individuals with uncomplicated malaria (reviewed Schofield and Grau, 2005; Good et al. 2005) and high concentrations of inflammatory cytokines in the cerebrospinal fluid are associated with a high risk of developing neurological sequelae (John et al. 2008). Very recently it has been shown that the binding of pRBCs to brain endothelial cells, causes the activation of the $\mathrm{NF}-\kappa \mathrm{B}$ pathway, leading to the production of CCL20, CXCL1, CXCL2, IL-6 and IL-8 (Tripathi et al. 2009). Despite this, the difficulty of carrying out mechanistic studies in humans means that it is not at all clear whether (and if so, how) these inflammatory responses lead to the onset of CM; however, direct effects, such as upregulation of endothelial ICAM-1 and VCAM-1 expression (Esslinger et al. 1994), and indirect effects, such as induction of fever leading to enhanced expression of PfEMP1 on pRBCs (Udomsangpetch et al. 2002), either of which might potentiate $\mathrm{pRBC}$ sequestration, have been suggested. Inflammatory cytokines may also be responsible for the presence of activated microglial cells (Schluesener et al. 1998), the main phagocytic macrophage-like cell population of the brain, and sequestered monocytes (Patnaik et al. 1994) in CM. It is possible that activated myeloid cells amplify the local intra-cerebral inflammatory response - by presenting antigen to $\mathrm{T}$ cells and/or producing inflammatory cytokines - but definitive exploration of this pathway in human CM is not feasible. The constraints imposed by gaining access to crucial tissues at key time-points in the onset of CM also explains the relative lack of data on the role of T cells in human CM. The only data that are available compare peripheral blood T cell populations in CM and non-CM cases and since it is clear that there is major re-alloacation of $\mathrm{T}$ cell subsets between the tissues and peripheral blood during acute malaria infection (Elhassan et al. 1994), these data are extremely difficult to interpret. Nevertheless, reductions in numbers of circulating $\mathrm{CD}^{+}$ $\mathrm{T}$ cells (reflecting either sequestration in tissues or activation-induced cell death) (Elhassan et al. 1994; Hviid et al. 1997) and increased frequencies of $\mathrm{CD}^{+}{ }^{+} \mathrm{T}$ cells expressing TCR V $\beta 21.3$ have been correlated with disease severity (Loizon et al. 2007). The potential for $\mathrm{CD}^{+} \mathrm{T}$ cells to play a role in the aetiology of human CM has not been systematically evaluated but there is no evidence as yet to implicate this population in the pathogenesis of CM.

Further evidence that the immune response plays a role in the pathogenesis of severe malaria comes from a series of studies designed to identify genetic polymorphisms that influence the risk of developing 
CM (Verra et al. 2009). Although there is a bias within the literature towards publication of positive associations the vast majority of reported associations involve genes that either affect parasite development within the red blood cell (e.g. haemoglobinopathies) or that moderate the strength and character of the immune response, for example TNF gene promoter variants (Knight et al. 1999; Cabantous et al. 2006; Clark et al. 2009) and interferon regulatory factor-1 gene variants (Koch et al. 2002; Mangano et al. 2008, 2009). The details of these associations vary from one population to another, likely reflecting differences in genetic background, but a clear message is beginning to emerge that is consistent with traits that lead to higher than average inflammatory responses being linked to increased risk of CM (Verra et al. 2009).

The idea that excessive pro-inflammatory immune responses pre-dispose to $\mathrm{CM}$ is also consistent with the clear age-related susceptibility to the development of $\mathrm{CM}$ in malaria endemic areas: very young children who have yet to acquire malariaspecific cellular immune responses are relatively resistant to CM (presenting instead with severe malarial anaemia) whereas older children - in whom previous malaria infections will have primed Th-1like adaptive immune responses - are at increased risk of CM. Epidemiological studies suggest that repeatedly exposed individuals eventually develop protective immunity (such that adults in endemic areas rarely develop $\mathrm{CM}$ ), which may be characterized by the ability to control parasite replication (keeping parasite densities below the critical threshold for induction of inflammation or impairment of cerebral blood flow), to prevent $\mathrm{pRBC}$ sequestration or to regulate the inflammatory process (ArtavanisTsakonas et al. 2003; Walther et al. 2009).

\section{Experimental cerebral malaria}

The vast majority of the immunological features of human $\mathrm{CM}$ are recapitulated during $P$. berghei ANKA infection. For example, the susceptibility of various inbred mouse strains to ECM has been directly correlated with the strength of the pro-inflammatory immune response to the parasite and to the response of microglial and cerebral endothethelial cells (e.g. upregulation of MHC Class I and Class II molecules, ICAM-1 and VCAM-1) to these inflammatory mediators (Lou et al. 1998, 2001; MonsoHinard et al. 1997; Randall et al. 2008 a). Moreover, experimental manipulation of $\mathrm{PbA}$-infected mice has allowed causal relationships to be established between specific immune responses and the development of ECM; in the main these relationships are entirely consistent with the associative observations from human studies. For example, administration of LPS, neutralization of IL-10 or heme oxygenase 1 or inhibition of CTLA-4 signalling during $\mathrm{PbA}$ infection all lead to the development of ECM in normally resistant mice (Kossodo et al. 1997; Neill and Hunt, 1995; Pamplona et al. 2007; J. Hafalla manuscript in preparation), whereas neutralization or ablation of IFN- $\gamma$, TNF and LT- $\alpha$ signalling or depletion of macrophages (by administration of clodronate liposomes) prevents the development of ECM in susceptible mouse strains (Grau et al. 1987, 1989; Curfs et al. 1993b; Rudin et al. 1997; Randall et al. 2008b; Engwerda et al. 2002; Amani et al. 2000; Togbe et al. 2008). Taken together, the wealth of experimental data indicates that the balance of Th-1 to T regulatory responses is critical in determining the outcome of $\mathrm{PbA}$ infection (Kossodo et al. 1997; Amante et al. 2007; Nie et al. 2007), whereas manipulation of Th-2 responses (for example by ablation of IL-4R signalling) does not substantially affect the outcome of infection (Saeftel et al. 2004). As in humans, circulating cytokines seem to activate cerebral endothelium, leading to increased expression of adhesion receptors, as well as upregulating chemokine production and chemokine receptor expression on leukocytes (Lou et al. 1998; Schofield and Grau, 2005; Good et al. 2005; Weiser et al. 2007) (Fig. 1).

It is well established that $\mathrm{CD}^{+}{ }^{+} \mathrm{T}$ cells play an essential role in the development of ECM: this has recently been reviewed in detail elsewhere (Renia et al. 2006). In summary, however, $\mathrm{CD}^{+} \mathrm{T}$ cells accumulate in the brains of susceptible but not resistant mice, in a CXCR3-, IP-10- (CXCL9), MIG(CXCL10) and platelet factor-4-dependent manner (Hansen et al. 2007; Miu et al. 2008; Van Den Steen et al. 2008; Campanella et al. 2008; Srivastava et al. 2008; Nie et al. 2009), immediately before the onset of neurological signs, and are believed to directly cause disruption of the blood-brain barrier and endothelial cell damage via perforin production (Nitcheu et al. 2003; Potter et al. 2006) (Fig. 1): depletion of $\mathrm{CD} 8{ }^{+} \mathrm{T}$ cells either early (from start of infection) or late (from day 4 or 5 post-infection) in infection completely inhibits the development of ECM (Yanez et al. 1996; Belnoue et al. 2002; Hermsen et al. 1997). CD8 ${ }^{+} \mathrm{T}$ cells migrate to the brain in a largely antigen-specific manner, following cross-presentation of malaria antigens by classical $\mathrm{CD}^{+}$dendritic cells (deWalick et al. 2007; Lundie et al. 2008; Miyakoda et al. 2008). The recent demonstration that NK cell-derived IFN- $\gamma$ is required for upregulation of CXCR 3 on $\mathrm{CD} 8^{+}{ }^{-} \mathrm{T}$ cells and for their subsequent migration to and accumulation within the brain (Hansen et al. 2007) is consistent with the observation that IFN- $\gamma \mathrm{R}$ signalling regulates sequestration of $\mathrm{CD} 8^{+} \mathrm{T}$ cells within the brain in susceptible mice (Belnoue et al. 2008), and reveals important interactions between innate and adaptive immune responses in the pathogenesis of ECM, opening up potential new avenues of research into the role of innate immune responses, and of 
genetic variation in innate response genes, in the pathogenesis of human CM.

It is clear that effector $\mathrm{CD}^{+}{ }^{+} \mathrm{T}$ cells also contribute to the development ECM, potentially by providing help to $\mathrm{CD} 8^{+} \mathrm{T}$ cells (Good et al. 2005); thus, it has been shown that depletion of $\mathrm{CD}^{+}$ $\mathrm{T}$ cells during the early (but not later) stages of $\mathrm{PbA}$ infection prevents the development of ECM (Belnoue et al. 2002). Nevertheless, in separate studies, depletion of $\mathrm{CD}^{+}{ }^{+} \mathrm{T}$ cells during the later stages of infection also prevented the development of ECM (Hermsen et al. 1997; Belnoue et al. 2008), implying that although far fewer $\mathrm{CD} 4^{+}$than $\mathrm{CD} 8^{+}$ $T$ cells accumulate in ECM brains (Belnoue et al. 2002), CD4 + T cells may also be involved in the effector phase of ECM. On the other hand, adoptive transfer of $\mathrm{PbA}$-specific $\mathrm{CD} 4{ }^{+} \mathrm{T}$ cells reduces parasite burdens and prevents ECM in semi-susceptible mice (Finley et al. 1983). Whether the protective and pathogenic functions of $\mathrm{CD} 4{ }^{+} \mathrm{T}$ cells are mediated by distinct subpopulations of $\mathrm{Th}$ cells, or is a consequence of the cellular location and/or the number of cells - all of which may potentially vary within different strains of inbred mice-requires further investigation.

The above section clearly describes the associated role of the pro-inflammatory immune response in the pathogenesis of CM and ECM. Leukocyte accumulation within the brain is a significant feature of $\mathrm{CM}$ and ECM, but, intriguingly, transmigration of leukocytes into the brain parenchyma does not appear to occur in either condition, indicating that the immunopathogenesis of CM is different from other cerebral pathologies, including Experimental Autoimmune Encephalitis and Multiple Sclerosis. Significantly more is understood regarding the immunological basis of ECM compared with human CM, where the relatively few studies performed are by necessity purely correlative. Consequently, it is impossible at present to definitively state whether the pathogenesis of $\mathrm{CM}$ is more or less immunemediated than ECM, and whether cells, such as $\mathrm{CD}^{+} \mathrm{T}$ cells, play comparable roles in the development of pathology in the two conditions. The ECM model provides valuable clues to processes that can lead to the development of pathology during malaria infection (Fig. 1), and should help to direct focused research to define the immunopathogenesis of CM.

IF ECM IS SUCH A GOOD MODEL FOR HUMAN CM WHY DO PREVENTIVE INTERVENTIONS IDENTIFIED IN ECM FAIL TO REDUCE THE MORBIDITY AND MORTALITY OF HUMAN CM?

The most important reason for developing a good model of CM is to identify and test novel therapies for prevention, attenuation or reversal of cerebral pathology. It is therefore disappointing that interventions, such as anti-TNF therapy (Grau et al. 1987) and dexamethasone (Neill and Hunt, 1995) that prevent the development of ECM have proven ineffective in humans (Hoffman et al. 1988; van Hensbroek et al. 1996). However, with hindsight, it is perhaps not surprising that treatments that prevent ECM when given prior to the development of neurological signs may not be able to reverse established CM pathologies, which is when they must be effective in clinical practice. Indeed, ablation of cytokine signalling, depletion of leukocyte populations and administration of blocking antibodies are all able to prevent, but not reverse, ECM (reviewed by Schofield and Grau 2005; Good et al. 2005). This does not necessarily mean, however, that findings from experimental models of CM are not relevant to treatment of CM in humans. Indeed, data showing that low bioavailability of $\mathrm{NO}$ contributes to the development of ECM in mice are analogous to results obtained in humans during $P$. falciparum infection (Gramglia et al. 2006; Yeo et al. 2007, 2008) and reversal of low NO bioavailability by administration of L-arginine or exogenous $\mathrm{NO}$ is protective in mice and humans (Gramglia et al. 2006; Yeo et al. 2007). Combined, these data have led to the current consideration of L-arginine therapy for phase II clinical trials in humans with CM. Similarly, the observation that erythropoietin protects susceptible mice from ECM (Kaiser et al. 2006) prompted comparison of erythropoietin levels in the plasma of uncomplicated and severe malaria patients CM (Casals-Pascual et al. 2008), leading to erythropoietin being considered as a potential adjunct therapy for CM (Casals-Pascual et al. 2009).

\section{CONCLUSIONS}

New adjunct therapies to improve the outcomes of cerebral malaria are urgently needed. Studies in humans are severely limited by lack of access to tissues, the impossibility of carrying out time-course studies and our inability to infer causality from associative clinical and epidemiological studies. Whilst not perfect, the neurological syndrome that develops in mice infected with $P$. berghei ANKA recapitulates most of the physiological, parasitological and immunological features of human CM. The ECM model has allowed the molecular and cellular basis of CM to be experimentally investigated and explained and has provided clues that have led to clinical trials of several potential new therapies. In the future, the application of increasingly sophisticated experimental techniques, including live imaging of parasite-host interactions (Wilson et al. 2009; Schaeffer et al. 2009; Ortolano et al. 2009), will allow us to develop an even greater understanding of the sequence of events leading to ECM. We will, for example, be able to determine whether cerebral inflammation precedes or follows $\mathrm{pRBC}$ sequestration, 
and whether brain-resident or brain-homing leukocytes are more important for the development of cerebral pathology, which will inform future decisions about appropriate immune-modulatory therapy. The now routine use of ophthalmoscopic examination of retinal pathology as a diagnostic tool for CM (White et al. 2009; Beare et al. 2006), which was first described in the experimental $P$. berghei ANKA model (Chang-Ling et al. 1992), demonstrates the importance of translational science in the understanding of cerebral malaria.

\section{REFERENCES}

Adams, S., Turner, G. D., Nash, G. B., Micklem, K., Newbold, C. I. and Craig, A. G. (2000). Differential binding of clonal variants of Plasmodium falciparum to allelic forms of intracellular adhesion molecule 1 determined by flow adhesion assay. Infection and Immunity 68, 264-269.

Aikawa, M., Brown, A., Smith, C. D., Tegoshi, T., Howard, R. J., Hasler, T. H., Ito, Y., Perry, G., Collins, W. E. and Webster, K. (1992). A primate model for human cerebral malaria: Plasmodium coatneyi-infected rhesus monkeys. American Yournal of Tropical Medicine and Hygiene 46, 391-397.

Amani, V., Vigario, A. M., Belnoue, E., Marussig, M., Fonseca, L., Mazier, D. and Renia, L. (2000). Involvement of IFN-gamma receptor-medicated signaling in pathology and anti-malarial immunity induced by Plasmodium berghei infection. European Fournal of Immunology 30, 1646-1655.

Amante, F. H., Stanley, A. C., Randall, L. M., Zhou, Y., Haque, A., Mcsweeney, K., Waters, A. P., Janse, C. J., Good, M. F., Hill, G. R. and Engwerda, C. R. (2007). A role for natural regulatory $\mathrm{T}$ cells in the pathogenesis of experimental cerebral malaria. American Fournal of Pathology 171, 548-559.

Artavanis-Tsakonas, K., Tongren, J. E. and Riley, E. M. (2003). The war between the malaria parasite and the immune system: immunity, immunoregulation and immunopathology. Clinical and Experimental Immunology 133, 145-152.

Bagot, S., Campino, S., Penha-Goncalves, C., Pied, S., Cazenave, P. A. and Holmberg, D. (2002).

Identification of two cerebral malaria resistance loci using an inbred wild-derived mouse strain. Proceedings of the National Academy of Sciences, USA 99, 9919-9923.

Baruch, D. I., Ma, X. C., Singh, H. B., Bi, X., Pasloske, B. L. and Howard, R. J. (1997). Identification of a region of PfEMP1 that mediates adherence of Plasmodium falciparum infected erythrocytes to CD36: conserved function with variant sequence. Blood 90, 3766-3775.

Baruch, D. I., Pasloske, B. L., Singh, H. B., Bi, X., Ma, X. C., Feldman, M., Taraschi, T. F. and Howard, R. J. (1995). Cloning the P. falciparum gene encoding PfEMP1, a malarial variant antigen and adherence receptor on the surface of parasitized human erythrocytes. Cell 82, 77-87.
Bate, C. A. and Kwiatkowski, D. P. (1994). Stimulators of tumour necrosis factor production released by damaged erythrocytes. Immunology 83, 256-261.

Beare, N. A., Taylor, T. E., Harding, S. P., Lewallen, S. and Molyneux, M. E. (2006). Malarial retinopathy: a newly established diagnostic sign in severe malaria. American Fournal of Tropical Medicine and Hygiene 75, 790-797.

Beeson, J. G., Reeder, J. C., Rogerson, S. J. and Brown, G. V. (2001). Parasite adhesion and immune evasion in placental malaria. Trends in Parasitology 17, 331-337.

Beghdadi, W., Porcherie, A., Schneider, B. S., Dubayle, D., Peronet, R., Huerre, M., Watanabe, T., Ohtsu, H., Louis, J. and Mecheri, S. (2008). Inhibition of histamine-mediated signaling confers significant protection against severe malaria in mouse models of disease. Fournal of Experimental Medicine 205, 395-408.

Bellamy, R., Kwiatkowski, D. and Hill, A. V. (1998). Absence of an association between intercellular adhesion molecule 1, complement receptor 1 and interleukin 1 receptor antagonist gene polymorphisms and severe malaria in a West African population. Transactions of the Royal Society of Tropical Medicine and Hygiene 92, 312-316.

Belnoue, E., Kayibanda, M., Vigario, A. M., Deschemin, J. C., Van Rooijen, N., Viguier, M., Snounou, G. and Renia, L. (2002). On the pathogenic role of brain-sequestered alphabeta CD8 $+\mathrm{T}$ cells in experimental cerebral malaria. Fournal of Immunology 169, 6369-6375.

Belnoue, E., Potter, S. M., Rosa, D. S., Mauduit, M., Gruner, A. C., Kayibanda, M., Mitchell, A. J., Hunt, N. H. and Renia, L. (2008). Control of pathogenic $\mathrm{CD} 8+\mathrm{T}$ cell migration to the brain by IFN-gamma during experimental cerebral malaria. Parasite Immunology 30, 544-553.

Berendt, A. R., Tumer, G. D. and Newbold, C. I. (1994). Cerebral malaria: the sequestration hypothesis. Parasitology Today 10, 412-414.

Boivin, M. J., Bangirana, P., Byarugaba, J., Opoka, R. O., Idro, R., Jurek, A. M. and John, C. C. (2007). Cognitive impairment after cerebral malaria in children: a prospective study. Pediatrics $\mathbf{1 1 9}$, e360-366.

Buffet, P. A., Gamain, B., Scheidig, C., Baruch, D., Smith, J. D., Hernandez-Rivas, R., Pouvelle, B., Oishi, S., Fujii, N., Fusai, T., Parzy, D., Miller, L. H., Gysin, J. and Scherf, A. (1999). Plasmodium falciparum domain mediating adhesion to chondroitin sulfate A: a receptor for human placental infection. Proceedings of the National Academy of Sciences, USA 96, 12743-12748.

Cabantous, S., Doumbo, O., Ranque, S., Poudiougou, B., Traore, A., Hou, X., Keita, M. M., Cisse, M. B., Dessein, A. J. and Marquet, S. (2006). Alleles 308A and $238 \mathrm{~A}$ in the tumor necrosis factor alpha gene promoter do not increase the risk of severe malaria in children with Plasmodium falciparum infection in Mali. Infection and Immunity 74, 7040-7042.

Campanella, G. S., Tager, A. M., E1 Khoury, J. K., Thomas, S. Y., Abrazinski, T. A., Manice, L. A., Colvin, R. A. and Luster, A. D. (2008). Chemokine 
receptor CXCR3 and its ligands CXCL9 and CXCL10 are required for the development of murine cerebral malaria. Proceedings of the National Academy of Sciences, USA 105, 4814-4819.

Campino, S., Bagot, S., Bergman, M. L., Almeida, P., Sepulveda, N., Pied, S., Penha-Goncalves, C., Holmberg, D. and Cazenave, P. A. (2005). Genetic control of parasite clearance leads to resistance to Plasmodium berghei ANKA infection and confers immunity. Genes \& Immunity 6, 416-421.

Carlton, J. M., Angiuoli, S. V., Suh, B. B., Kooij, T. W., Pertea, M., Silva, J. C., Ermolaeva, M. D., Allen, J. E., Selengut, J. D., Koo, H. L., Peterson, J. D., Pop, M., Kosack, D. S., Shumway, M. F., Bidwell, S. L., Shallom, S. J., Van Aken, S. E., Riedmuller, S. B., Feldblyum, T. V., Cho, J. K., Quackenbush, J., Sedegah, M., Shoaibi, A., Cummings, L. M., Florens, L., Yates, J. R., Raine, J. D., Sinden, R. E., Harris, M. A., Cunningham, D. A., Preiser, P. R., Bergman, L. W., Vaidya, A. B., Van Lin, L. H., Janse, C. J., Waters, A. P., Smith, H. O., White, O. R., Salzberg, S. L., Venter, J. C., Fraser, C. M., Hoffman, S. L., Gardner, M. J. and Carucci, D. J. (2002). Genome sequence and comparative analysis of the model rodent malaria parasite Plasmodium yoelii yoelii. Nature, London 419, 512-519.

Carter, J. A., Mung'ala-Odera, V., Neville, B. G., Murira, G., Mturi, N., Musumba, C. and Newton, C. R. (2005a). Persistent neurocognitive impairments associated with severe falciparum malaria in Kenyan children. Fournal of Neurology, Neurosurgery $\boldsymbol{E}^{\circ}$ Psychiatry 76, 476-481.

Carter, J. A., Ross, A. J., Neville, B. G., Obiero, E., Katana, K., Mung'ala-Odera, V., Lees, J. A. and Newton, C. R. (2005b). Developmental impairments following severe falciparum malaria in children. Tropical Medicine E International Health 10, 3-10.

Casals-Pascual, C., Idro, R., Gicheru, N., Gwer, S., Kitsao, B., Gitau, E., Mwakesi, R., Roberts, D. J. and Newton, C. R. (2008). High levels of erythropoietin are associated with protection against neurological sequelae in African children with cerebral malaria. Proceedings of the National Academy of Sciences, USA 105, 2634-2639.

Casals-Pascual, C., Idro, R., Picot, S., Roberts, D. J. and Newton, C. R. (2009). Can erythropoietin be used to prevent brain damage in cerebral malaria? Trends in Parasitology 25, 30-36.

Chakravorty, S. J. and Craig, A. (2005). The role of ICAM-1 in Plasmodium falciparum cytoadherence. European Fournal of Cell Biology 84, 15-27.

Chakravorty, S. J., Hughes, K. R. and Craig, A. G. (2008). Host response to cytoadherence in Plasmodium falciparum. Biochemical Society Transactions 36, 221-228.

Chang-Ling, T., Neill, A. L. and Hunt, N. H. (1992). Early microvascular changes in murine cerebral malaria detected in retinal wholemounts. American Fournal of Pathology 140, 1121-1130.

Chen, Q., Barragan, A., Fernandez, V., Sundstrom, A., Schlichtherle, M., Sahlen, A., Carlson, J., Datta, S. and Wahlgren, M. (1998). Identification of Plasmodium falciparum erythrocyte membrane protein 1 (PfEMP1) as the rosetting ligand of the malaria parasite P. falciparum. Fournal of Experimental Medicine 187, 15-23.

Clark, C. J., Phillips, R. S., McMillan, R. B., Montgomery, I. O. and Stone, T. W. (2005). Differences in the neurochemical characteristics of the cortex and striatum of mice with cerebral malaria. Parasitology 130, 23-29.

Clark, I. A., Awburn, M. M., Whitten, R. O., Harper, C. G., Liomba, N. G., Molyneux, M. E. and Taylor, T. E. (2003). Tissue distribution of migration inhibitory factor and inducible nitric oxide synthase in falciparum malaria and sepsis in African children. Malaria Fournal 2, 6.

Clark, I. A., Budd, A. C., Alleva, L. M. and Cowden, W. B. (2006). Human malarial disease: a consequence of inflammatory cytokine release. Malaria Fournal 5, 85 .

Clark, T. G., Diakite, M., Auburn, S., Campino, S., Fry, A. E., Green, A., Richardson, A., Small, K., Teo, Y. Y., Wilson, J., Jallow, M., Sisay-Joof, F., Pinder, M., Griffiths, M. J., Peshu, N., Williams, T. N., Marsh, K., Molyneux, M. E., Taylor, T. E., Rockett, K. A. and Kwiatkowski, D. P. (2009). Tumor necrosis factor and lymphotoxin-alpha polymorphisms and severe malaria in African populations. Fournal of Infectious Diseases 199, 569-575.

Coltel, N., Combes, V., Wassmer, S. C., Chimini, G. and Grau, G. E. (2006). Cell vesiculation and immunopathology: implications in cerebral malaria. Microbes and Infection 8, 2305-2316.

Combes, V., Rosenkranz, A. R., Redard, M., Pizzolato, G., Lepidi, H., Vestweber, D., Mayadas, T. N. and Grau, G. E. (2004). Pathogenic role of $\mathrm{P}$-selectin in experimental cerebral malaria: importance of the endothelial compartment. American Fournal of Pathology 164, 781-786.

Couper, K. N., Blount, D. G., Hafalla, J. C., Van Rooijen, N., De Souza, J. B. and Riley, E. M. (2007). Macrophage-mediated but gamma interferonindependent innate immune responses control the primary wave of Plasmodium yoelii parasitemia. Infection and Immunity 75, 5806-5818.

Couper, K. N., Blount, D. G., Wilson, M. S., Hafalla, J. C., Belkaid, Y., Kamanaka, M., Flavell, R. A., De Souza, J. B. and Riley, E. M. (2008). IL-10 from CD4CD25Foxp3CD127 adaptive regulatory T cells modulates parasite clearance and pathology during malaria infection. PLoS Pathogens 4, e1000004.

Crawley, J., Smith, S., Kirkham, F., Muthinji, P., Waruiru, C. and Marsh, K. (1996). Seizures and status epilepticus in childhood cerebral malaria. Quarterly Fournal of Medicine 89, 591-597.

Cunningham, D. A., Jarra, W., Koernig, S., Fonager, J., Fernandez-Reyes, D., Blythe, J. E., Waller, C., Preiser, P. R. and Langhorne, J. (2005). Host immunity modulates transcriptional changes in a multigene family (yir) of rodent malaria. Molecular Microbiology 58, 636-647.

Curfs, J. H., Hermsen, C. C., Kremsner, P., Neifer, S., Meuwissen, J. H., Van Rooyen, N. and Eling, W. M. $(1993 b)$. Tumour necrosis factor-alpha and macrophages in Plasmodium berghei-induced cerebral malaria. Parasitology 107, 125-134.

Curfs, J. H., Van Der Meide, P. H., Billiau, A., Meuwissen, J. H. and Eling, W. M. (1993a). 
Plasmodium berghei: recombinant interferon-gamma and the development of parasitemia and cerebral lesions in malaria-infected mice. Experimental Parasitology 77, 212-223.

De Souza, J. B. and Riley, E. M. (2002). Cerebral malaria: the contribution of studies in animal models to our understanding of immunopathogenesis. Microbes and Infection 4, 291-300.

Del Portillo, H. A., Fernandez-Becerra, C., Bowman, S., Oliver, K., Preuss, M., Sanchez, C. P., Schneider, N. K., Villalobos, J. M., Rajandream, M. A., Harris, D., Pereira Da Silva, L. H., Barrell, B. and Lanzer, M. (2001). A superfamily of variant genes encoded in the subtelomeric region of Plasmodium vivax. Nature, London 410, 839-842.

Delahaye, N. F., Coltel, N., Puthier, D., Barbier, M., Benech, P., Joly, F., Iraqi, F. A., Grau, G. E., Nguyen, C. and Rihet, P. (2007). Gene expression analysis reveals early changes in several molecular pathways in cerebral malaria-susceptible mice versus cerebral malaria-resistant mice. BMC Genomics, 8, 452-467.

Desruisseaux, M. S., Gulinello, M., Smith, D. N., Lee, S. C., Tsuji, M., Weiss, L. M., Spray, D. C. and Tanowitz, H. B. (2008). Cognitive dysfunction in mice infected with Plasmodium berghei strain ANKA. Fournal of Infectious Diseases 197, 1621-1627.

Dewalick, S., Amante, F. H., Mcsweeney, K. A., Randall, L. M., Stanley, A. C., Haque, A., Kuns, R. D., Macdonald, K. P., Hill, G. R. and Engwerda, C. R. (2007). Cutting edge: conventional dendritic cells are the critical APC required for the induction of experimental cerebral malaria. Fournal of Immunology 178, 6033-6037.

Dondorp, A., Nosten, F., Stepniewska, K., Day, N. and White, N. (2005a). Artesunate versus quinine for treatment of severe falciparum malaria: a randomised trial. Lancet 366, 717-725.

Dondorp, A. M., Desakorn, V., Pongtavornpinyo, W., Sahassananda, D., Silamut, K., Chotivanich, K., Newton, P. N., Pitisuttithum, P., Smithyman, A. M., White, N. J. and Day, N. P. (2005 $b$ ). Estimation of the total parasite biomass in acute falciparum malaria from plasma PfHRP2. PLoS Medicine 2, e204.

Elhassan, I. M., Hviid, L., Satti, G., Akerstrom, B., Jakobsen, P. H., Jensen, J. B. and Theander, T. G. (1994). Evidence of endothelial inflammation, $\mathrm{T}$ cell activation, and $\mathrm{T}$ cell reallocation in uncomplicated Plasmodium falciparum malaria. American Fournal of Tropical Medicine and Hygiene 51, 372-379.

Engwerda, C. R., Beattie, L. and Amante, F. H. (2005). The importance of the spleen in malaria. Trends in Parasitology 21, 75-80.

Engwerda, C. R., Mynott, T. L., Sawhney, S., De Souza, J. B., Bickle, Q. D. and Kaye, P. M. (2002). Locally up-regulated lymphotoxin alpha, not systemic tumor necrosis factor alpha, is the principle mediator of murine cerebral malaria. Fournal of Experimental Medicine 195, 1371-1377.

Esslinger, C. W., Picot, S. and Ambroise-Thomas, P. (1994). Intra-erythrocytic Plasmodium falciparum induces up-regulation of inter-cellular adhesion molecule-1 on human endothelial cells in vitro. Scandinavian Fournal of Immunology 39, 229-232.
Faille, D., Combes, V., Mitchell, A. J., Fontaine, A., Juhan-Vague, I., Alessi, M. C., Chimini, G., Fusai, T. and Grau, G. E. (2009). Platelet microparticles: a new player in malaria parasite cytoadherence to human brain endothelium. FASEB Fournal 23, 3449-3458.

Favre, N., Da Laperousaz, C., Ryffel, B., Weiss, N. A., Imhof, B. A., Rudin, W., Lucas, R. and Piguet, P. F. (1999). Role of ICAM-1 (CD54) in the development of murine cerebral malaria. Microbes and Infection $\mathbf{1}$ 961-968

Fernandez-Reyes, D., Craig, A. G., Kyes, S. A., Peshu, N., Snow, R. W., Berendt, A. R., Marsh, K. and Newbold, C. I. (1997). A high frequency African coding polymorphism in the $\mathrm{N}$-terminal domain of ICAM-1 predisposing to cerebral malaria in Kenya. Human Molecular Genetics 6, 1357-1360.

Finley, R., Weintraub, J., Louis, J. A., Engers, H. D., Zubler, R. and Lambert, P. H. (1983). Prevention of cerebral malaria by adoptive transfer of malaria-specific cultured T cells into mice infected with Plasmodium berghei. Fournal of Immunology 131, 1522-1526.

Franke-Fayard, B., Janse, C. J., Cunha-Rodrigues, M., Ramesar, J., Buscher, P., Que, I., Lowik, C., Voshol, P. J., Den Boer, M. A., Van Duinen, S. G., Febbraio, M., Mota, M. M. and Waters, A. P. (2005). Murine malaria parasite sequestration: CD36 is the major receptor, but cerebral pathology is unlinked to sequestration. Proceedings of the National Academy of Sciences, USA 102, 11468-11473.

Fried, M. and Duffy, P. E. (2002). Two DBLgamma subtypes are commonly expressed by placental isolates of Plasmodium falciparum. Molecular and Biochemical Parasitology 122, 201-210.

Fry, A. E., Auburn, S., Diakite, M., Green, A., Richardson, A., Wilson, J., Jallow, M., Sisay-Joof, F., Pinder, M., Griffiths, M. J., Peshu, N., Williams, T. N., Marsh, K., Molyneux, M. E., Taylor, T. E., Rockett, K. A. and Kwiatkowski, D. P. (2008). Variation in the ICAM1 gene is not associated with severe malaria phenotypes. Genes $\mathcal{E}^{\circ}$ Immunity $\mathbf{9}$, 462-469.

Gamain, B., Smith, J. D., Avril, M., Baruch, D. I., Scherf, A., Gysin, J. and Miller, L. H. (2004). Identification of a 67-amino-acid region of the Plasmodium falciparum variant surface antigen that binds chondroitin sulphate $\mathrm{A}$ and elicits antibodies reactive with the surface of placental isolates. Molecular Microbiology 53, 445-455.

Gardner, J. P., Pinches, R. A., Roberts, D. J. and Newbold, C. I. (1996). Variant antigens and endothelial receptor adhesion in Plasmodium falciparum. Proceedings of the National Academy of Sciences, USA 93, 3503-3508.

Good, M. F., Xu, H., Wykes, M. and Engwerda, C. R. (2005). Development and regulation of cell-mediated immune responses to the blood stages of malaria: implications for vaccine research. Annual Review of Immunology 23, 69-99.

Gramaglia, I., Sobolewski, P., Meays, D., Contreras, R., Nolan, J. P., Frangos, J. A., Intaglietta, M. and Van Der Heyde, H. C. (2006). Low nitric oxide bioavailability contributes to the genesis of experimental cerebral malaria. Nature Medicine 12, 1417-1422. 
Grau, G. E., Fajardo, L. F., Piguet, P. F., Allet, B., Lambert, P. H. and Vassalli, P. (1987). Tumor necrosis factor (cachectin) as an essential mediator in murine cerebral malaria. Science 237, 1210-1212.

Grau, G. E., Heremans, H., Piguet, P. F., Pointaire, P., Lambert, P. H., Billiau, A. and Vassalli, P. (1989). Monoclonal antibody against interferon gamma can prevent experimental cerebral malaria and its associated overproduction of tumor necrosis factor. Proceedings of the National Academy of Sciences, USA 86, 5572-5574.

Gray, C., McCormick, C., Turner, G. and Craig, A. (2003). ICAM-1 can play a major role in mediating $P$. falciparum adhesion to endothelium under flow. Molecular and Biochemical Parasitology 128, 187-193.

Gysin, J., Aikawa, M., Tourneur, N. and Tegoshi, T. (1992). Experimental Plasmodium falciparum cerebral malaria in the squirrel monkey Saimiri sciureus. Experimental Parasitology 75, 390-398.

Haldar, K., Murphy, S. C., Milner, D. A. and Taylor, T. E. (2007). Malaria: mechanisms of erythrocytic infection and pathological correlates of severe disease. Annual Review of Pathology 2, 217-249.

Hansen, D. S., Bernard, N. J., Nie, C. Q. and Schofield, L. (2007). NK cells stimulate recruitment of CXCR3 + T cells to the brain during Plasmodium berghei-mediated cerebral malaria. Fournal of Immunology 178, 5779-5788.

Hau, J. and Van Hoosier, G. L. Jr. (2005). Handbook of Laboratory Animal Science. 2nd Edn. CRC Press, Boca Raton, FL, USA.

Hearn, J., Rayment, N., Landon, D. N., Katz, D. R. and De Souza, J. B. (2000). Immunopathology of cerebral malaria: morphological evidence of parasite sequestration in murine brain microvasculature. Infection and Immunity 68, 5364-5376.

Heddini, A., Pettersson, F., Kai, O., Shafi, J., Obiero, J., Chen, Q., Barragan, A., Wahlgren, M. and Marsh, K. (2001). Fresh isolates from children with severe Plasmodium falciparum malaria bind to multiple receptors. Infection and Immunity 69, 5849-5856.

Hermsen, C., Van De Wiel, T., Mommers, E., Sauerwein, R. and Eling, W. (1997). Depletion of CD4 + or CD8 + T-cells prevents Plasmodium berghei induced cerebral malaria in end-stage disease. Parasitology 114, 7-12.

Ho, M., Schollaardt, T., Niu, X., Looareesuwan, S., Patel, K. D. and Kubes, P. (1998). Characterization of Plasmodium falciparum-infected erythrocyte and P-selectin interaction under flow conditions. Blood 91, 4803-4809.

Hoffman, S. L., Rustama, D., Punjabi, N. H., Surampaet, B., Sanjaya, B., Dimpudus, A. J., Mckee, K. T. Jr., Paleologo, F. P., Campbell, J. R., Marwoto, H. and Laughlin, L. (1988). High-dose dexamethasone in quinine-treated patients with cerebral malaria: a double-blind, placebo-controlled trial. Fournal of Infectious Diseases 158, 325-331.

Hunt, N. H., Golenser, J., Chan-Ling, T., Parekh, S., Rae, C., Potter, S., Medana, I. M., Miu, J. and Ball, H. J. (2006). Immunopathogenesis of cerebral malaria. International Fournal for Parasitology 36, 569-582.

Hviid, L., Kurtzhals, J. A., Goka, B. Q., Oliver-Commey, J. O., Nkrumah, F. K. and
Theander, T. G. (1997). Rapid reemergence of T cells into peripheral circulation following treatment of severe and uncomplicated Plasmodium falciparum malaria. Infection and Immunity 65, 4090-4093.

Ibiwoye, M. O., Howard, C. V., Sibbons, P., Hasan, M. and Van Velzen, D. (1993). Cerebral malaria in the rhesus monkey (Macaca mulatta): observations on host pathology. Fournal of Comparative Pathology 108, 303-310.

Idro, R., Jenkins, N. E. and Newton, C. R. (2005). Pathogenesis, clinical features, and neurological outcome of cerebral malaria. Lancet Neurology 4 , $827-840$.

Janssen, C. S., Barrett, M. P., Turner, C. M. and Phillips, R. S. (2002). A large gene family for putative variant antigens shared by human and rodent malaria parasites. Proceedings of the Royal Society of London, $B$ 269, 431-436.

Jennings, V. M., Lal, A. A. and Hunter, R. L. (1998). Evidence for multiple pathologic and protective mechanisms of murine cerebral malaria. Infection and Immunity 66, 5972-5979.

Jensen, A. T., Magistrado, P., Sharp, S., Joergensen, L., Lavstsen, T., Chiucchiuini, A., Salanti, A., Vestergaard, L. S., Lusingu, J. P., Hermsen, R., Sauerwein, R., Christensen, J., Nielsen, M. A., Hviid, L., Sutherland, C., Staalsoe, T. and Theander, T. G. (2004). Plasmodium falciparum associated with severe childhood malaria preferentially expresses PfEMP1 encoded by group A var genes. Fournal of Experimental Medicine 199, 1179-1190.

John, C. C., Panoskaltsis-Mortari, A., Opoka, R. O., Park, G. S., Orchard, P. J., Jurek, A. M., Idro, R., Byarugaba, J. and Boivin, M. J. (2008). Cerebrospinal fluid cytokine levels and cognitive impairment in cerebral malaria. American Fournal of Tropical Medicine and Hygiene 78, 198-205.

Johnson, J. K., Swerlick, R. A., Grady, K. K., Millet, P. and Wick, T. M. (1993). Cytoadherence of Plasmodium falciparum-infected erythrocytes to microvascular endothelium is regulatable by cytokines and phorbol ester. Fournal of Infectious Diseases 167, 698-703.

Kaiser, K., Texier, A., Ferrandiz, J., Buguet, A., Meiller, A., Latour, C., Peyron, F., Cespuglio, R. and Picot, S. (2006). Recombinant human erythropoietin prevents the death of mice during cerebral malaria. Fournal of Infectious Diseases 193, 987-995.

Kampfl, A. W., Birbamer, G. G., Pfausler, B. E., Haring, H. P. and Schmutzhard, E. (1993). Isolated pontine lesion in algid cerebral malaria: clinical features, management, and magnetic resonance imaging findings. American Fournal of Tropical Medicine and Hygiene 48, 818-822.

Kaul, D. K., Nagel, R. L., Llena, J. F. and Shear, H. L. (1994). Cerebral malaria in mice: demonstration of cytoadherence of infected red blood cells and microrheologic correlates. American Fournal of Tropical Medicine and Hygiene 50, 512-521.

Knight, J. C., Udalova, I., Hill, A. V., Greenwood, B. M., Peshu, N., Marsh, K. and Kwiatkowski, D. (1999). A polymorphism that affects OCT-1 binding to 
the TNF promoter region is associated with severe malaria. Nature Genetics 22, 145-150.

Koch, O., Awomoyi, A., Usen, S., Jallow, M., Richardson, A., Hull, J., Pinder, M., Newport, M. and Kwiatkowski, D. (2002). IFNGR1 gene promoter polymorphisms and susceptibility to cerebral malaria. Fournal of Infectious Diseases 185, 1684-1687.

Kossodo, S., Monso, C., Juillard, P., Velu, T., Goldman, M. and Grau, G. E. (1997). Interleukin-10 modulates susceptibility in experimental cerebral malaria. Immunology 91, 536-540.

Kremsner, P. G., Grundmann, H., Neifer, S., Sliwa, K., Sahlmuller, G., Hegenscheid, B. and Bienzle, U. (1991). Pentoxifylline prevents murine cerebral malaria. Fournal of Infectious Diseases $\mathbf{1 6 4}$, 605-608.

Lackner, P., Beer, R., Helbok, R., Broessner, G., Engelhardt, K., Brenneis, C., Schmutzhard, E. and Pfaller, K. (2006). Scanning electron microscopy of the neuropathology of murine cerebral malaria. Malaria Fournal 5, 116.

Li, J., Chang, W. L., Sun, G., Chen, H. L., Specian, R. D., Berney, S. M., Kimpel, D., Granger, D. N. and Van Der Heyde, H. C. (2003). Intercellular adhesion molecule 1 is important for the development of severe experimental malaria but is not required for leukocyte adhesion in the brain. Fournal of Investigative Medicine 51, 128-140.

Loizon, S., Boeuf, P., Tetteh, J. K., Goka, B., Obeng-Adjei, G., Kurtzhals, J. A., Rogier, C., Akanmori, B. D., Mercereau-Puijalon, O., Hviid, L. and Behr, C. (2007). V beta profiles in African children with acute cerebral or uncomplicated malaria: very focused changes among a remarkable global stability. Microbes and Infection 9, 1252-1259.

Lou, J., Gasche, Y., Zheng, L., Critico, B., MonsoHinard, C., Juillard, P., Morel, P., Buurman, W. A. and Grau, G. E. (1998). Differential reactivity of brain microvascular endothelial cells to TNF reflects the genetic susceptibility to cerebral malaria. European Fournal of Immunology 28, 3989-4000.

Lou, J., Lucas, R. and Grau, G. E. (2001). Pathogenesis of cerebral malaria: recent experimental data and possible applications for humans. Clinical Microbiology Reviews 14, 810-820.

Lovegrove, F. E., Gharib, S. A., Patel, S. N., Hawkes, C. A., Kain, K. C. and Liles, W. C. (2007). Expression microarray analysis implicates apoptosis and interferon-responsive mechanisms in susceptibility to experimental cerebral malaria. American Fournal of Pathology 171, 1894-1903.

Lovegrove, F. E., Gharib, S. A., Pena-Castillo, L., Patel, S. N., Ruzinski, J. T., Hughes, T. R., Liles, W. C. and Kain, K. C. (2008). Parasite burden and CD36-mediated sequestration are determinants of acute lung injury in an experimental malaria model. PLoS Pathogens 4, e1000068.

Lundie, R. J., De Koning-Ward, T. F., Davey, G. M., Nie, C. Q., Hansen, D. S., Lau, L. S., Mintern, J. D., Belz, G. T., Schofield, L., Carbone, F. R., Villadangos, J. A., Crabb, B. S. and Heath, W. R. (2008). Blood-stage Plasmodium infection induces $\mathrm{CD} 8+\mathrm{T}$ lymphocytes to parasite-expressed antigens, largely regulated by CD8alpha + dendritic cells.
Proceedings of the National Academy of Sciences, USA 105, 14509-14514.

Mangano, V. D., Clark, T. G., Auburn, S., Campino, S., Diakite, M., Fry, A. E., Green, A., Richardson, A., Jallow, M., Sisay-Joof, F., Pinder, M., Griffiths, M. J., Newton, C., Peshu, N., Williams, T. N., Marsh, K., Molyneux, M. E., Taylor, T. E., Modiano, D., Kwiatkowski, D. P. and Rockett, K. A. (2009). Lack of association of interferon regulatory factor 1 with severe malaria in affected child-parental trio studies across three African populations. PLoS One 4, e4206.

Mangano, V. D., Luoni, G., Rockett, K. A., Sirima, B. S., Konate, A., Forton, J., Clark, T. G., Bancone, G., Sadighi Akha, E., Kwiatkowski, D. P. and Modiano, D. (2008). Interferon regulatory factor-1 polymorphisms are associated with the control of Plasmodium falciparum infection. Genes E Immunity 9. 122-129

Marsh, K. and Snow, R. W. (1999). Malaria transmission and morbidity. Parassitologia 41, 241-246.

McCormick, C. J., Craig, A., Roberts, D., Newbold, C. I. and Berendt, A. R. (1997). Intercellular adhesion molecule-1 and CD36 synergize to mediate adherence of Plasmodium falciparum-infected erythrocytes to cultured human microvascular endothelial cells. The Fournal of Clinical Investigation 100, 2521-2529.

McLean, S. A., Pearson, C. D. and Phillips, R. S. (1986). Antigenic variation in Plasmodium chabaudi: analysis of parent and variant populations by cloning. Parasite Immunology 8, 415-424.

Medana, I. M., Hunt, N. H. and Chan-Ling, T. (1997a). Early activation of microglia in the pathogenesis of fatal murine cerebral malaria. Glia 19, 91-103.

Medana, I. M., Hunt, N. H. and Chaudhri, G. (1997 b) Tumor necrosis factor-alpha expression in the brain during fatal murine cerebral malaria: evidence for production by microglia and astrocytes. American Fournal of Pathology 150, 1473-1486.

Mishra, S. K. and Wiese, L. (2009). Advances in the management of cerebral malaria in adults. Current Opinion in Neurology 22, 302-307.

Mitchell, A. J., Hansen, A. M., Hee, L., Ball, H. J., Potter, S. M., Walker, J. C. and Hunt, N. H. (2005). Early cytokine production is associated with protection from murine cerebral malaria. Infection and Immunity 73, 5645-5653.

Miu, J., Mitchell, A. J., Muller, M., Carter, S. L., Manders, P. M., McQuillan, J. A., Saunders, B. M., Ball, H. J., Lu, B., Campbell, I. L. and Hunt, N. H. (2008). Chemokine gene expression during fatal murine cerebral malaria and protection due to CXCR3 deficiency. Fournal of Immunology 180, 1217-1230.

Miyakoda, M., Kimura, D., Yuda, M., Chinzei, Y., Shibata, Y., Honma, K. and Yui, K. (2008). Malaria-specific and nonspecific activation of CD8+ T cells during blood stage of Plasmodium berghei infection. Fournal of Immunology 181, 1420-1428.

Molyneux, M. E., Taylor, T. E., Wirima, J. J. and Borgstein, A. (1989). Clinical features and prognostic indicators in paediatric cerebral malaria: a study of 131 comatose Malawian children. Quarterly Fournal of Medicine 71, 441-459. 
Monso-Hinard, C., Lou, J. N., Behr, C., Juillard, P. and Grau, G. E. (1997). Expression of major histocompatibility complex antigens on mouse brain microvascular endothelial cells in relation to susceptibility to cerebral malaria. Immunology $\mathbf{9 2}$, 53-59.

Nagayasu, E., Nagakura, K., Akaki, M., Tamiya, G., Makino, S., Nakano, Y., Kimura, M. and Aikawa, M. (2002). Association of a determinant on mouse chromosome 18 with experimental severe Plasmodium berghei malaria. Infection and Immunity 70, 512-516.

Neill, A. L. and Hunt, N. H. (1995). Effects of endotoxin and dexamethasone on cerebral malaria in mice. Parasitology 111, 443-454.

Newbold, C., Craig, A., Kyes, S., Rowe, A., Fernandez-Reyes, D. and Fagan, T. (1999). Cytoadherence, pathogenesis and the infected red cell surface in Plasmodium falciparum. International Fournal for Parasitology 29, 927-937.

Nie, C. Q., Bernard, N. J., Norman, M. U., Amante, F. H., Lundie, R. J., Crabb, B. S., Heath, W. R., Engwerda, C. R., Hickey, M. J., Schofield, L. and Hansen, D. S. (2009). IP-10-mediated T cell homing promotes cerebral inflammation over splenic immunity to malaria infection. PLoS Pathogens 5, e1000369.

Nie, C. Q., Bernard, N. J., Schofield, L. and Hansen, D. S. (2007). CD $4+$ CD $25+$ regulatory $\mathrm{T}$ cells suppress CD4 + T-cell function and inhibit the development of Plasmodium berghei-specific TH1 responses involved in cerebral malaria pathogenesis. Infection and Immunity 75, 2275-2282.

Nitcheu, J., Bonduelle, O., Combadiere, C., Tefit, M., Seilhean, D., Mazier, D. and Combadiere, B. (2003). Perforin-dependent brain-infiltrating cytotoxic CD8 + T lymphocytes mediate experimental cerebral malaria pathogenesis. Fournal of Immunology 170, 2221-2228.

Normark, J., Nilsson, D., Ribacke, U., Winter, G., Moll, K., Wheelock, C. E., Bayarugaba, J., Kironde, F., Egwang, T. G., Chen, Q., Andersson, B. and Wahlgren, M. (2007). PfEMP1-DBL1alpha amino acid motifs in severe disease states of Plasmodium falciparum malaria. Proceedings of the National Academy of Sciences, USA 104, 15835-15840.

Oakley, M. S., McCutchan, T. F., Anantharaman, V., Ward, J. M., Faucette, L., Erexson, C., Mahajan, B., Zheng, H., Majam, V., Aravind, L. and Kumar, S. (2008). Host biomarkers and biological pathways that are associated with the expression of experimental cerebral malaria in mice. Infection and Immunity $\mathbf{7 6}$, 4518-4529.

Ockenhouse, C. F., Ho, M., Tandon, N. N., Van Seventer, G. A., Shaw, S., White, N. J., Jamieson, G. A., Chulay, J. D. and Webster, H. K. (1991). Molecular basis of sequestration in severe and uncomplicated Plasmodium falciparum malaria: differential adhesion of infected erythrocytes to CD36 and ICAM-1. Fournal of Infectious Diseases 164, 163-169.

Ockenhouse, C. F., Tandon, N. N., Magowan, C., Jamieson, G. A. and Chulay, J. D. (1989). Identification of a platelet membrane glycoprotein as a falciparum malaria sequestration receptor. Science 243, 1469-1471.
Ockenhouse, C. F., Tegoshi, T., Maeno, Y., Benjamin, C., Ho, M., Kan, K. E., Thway, Y., Win, K., Aikawa, M. and Lobb, R. R. (1992).

Human vascular endothelial cell adhesion receptors for Plasmodium falciparum-infected erythrocytes: roles for endothelial leukocyte adhesion molecule 1 and vascular cell adhesion molecule 1. Fournal of Experimental Medicine 176, 1183-1189.

Ohno, T. and Nishimura, M. (2004). Detection of a new cerebral malaria susceptibility locus, using CBA mice. Immunogenetics 56, 675-678.

Oleinikov, A. V., Amos, E., Frye, I. T., Rossnagle, E., Mutabingwa, T. K., Fried, M. and Duffy, P. E. (2009). High throughput functional assays of the variant antigen PfEMP1 reveal a single domain in the 3D7 Plasmodium falciparum genome that binds ICAM1 with high affinity and is targeted by naturally acquired neutralizing antibodies. PLoS Pathogens 5, e1000386.

Ortolano, F., Maffia, P., Dever, G., Hutchison, S., Benson, R., Millington, O. R., De Simoni, M. G., Bushell, T. J., Garside, P., Carswell, H. V. and Brewer, J. M. (2009). Imaging T-cell movement in the brain during experimental cerebral malaria. Parasite Immunology 31, 147-150.

Pais, T. F. and Chatterjee, S. (2005). Brain macrophage activation in murine cerebral malaria precedes accumulation of leukocytes and CD8 $+\mathrm{T}$ cell proliferation. Fournal of Neuroimmunology 163, 73-83.

Pamplona, A., Ferreira, A., Balla, J., Jeney, V., Balla, G., Epiphanio, S., Chora, A., Rodrigues, C. D., Gregoire, I. P., Cunha-Rodrigues, M., Portugal, S., Soares, M. P. and Mota, M. M. (2007). Heme oxygenase- 1 and carbon monoxide suppress the pathogenesis of experimental cerebral malaria. Nature Medicine 13, 703-710.

Patankar, T. F., Karnad, D. R., Shetty, P. G., Desai, A. P. and Prasad, S. R. (2002). Adult cerebral malaria: prognostic importance of imaging findings and correlation with postmortem findings. Radiology 224, 811-816.

Patnaik, J. K., Das, B. S., Mishra, S. K., Mohanty, S., Satpathy, S. K. and Mohanty, D. (1994). Vascular clogging, mononuclear cell margination, and enhanced vascular permeability in the pathogenesis of human cerebral malaria. American Fournal of Tropical Medicine and Hygiene 51, 642-647.

Penet, M. F., Kober, F., Confort-Gouny, S., Le Fur, Y., Dalmasso, C., Coltel, N., Liprandi, A., Gulian, J. M., Grau, G. E., Cozzone, P. J. and Viola, A. (2007). Magnetic resonance spectroscopy reveals an impaired brain metabolic profile in mice resistant to cerebral malaria infected with Plasmodium berghei ANKA. Fournal of Biological Chemistry 282, 14505-14514.

Penet, M. F., Viola, A., Confort-Gouny, S., Le Fur, Y., Duhamel, G., Kober, F., Ibarrola, D., Izquierdo, M., Coltel, N., Gharib, B., Grau, G. E. and Cozzone, P. J. (2005). Imaging experimental cerebral malaria in vivo: significant role of ischemic brain edema. Fournal of Neuroscience 25, 7352-7358.

Potter, S., Chan-Ling, T., Ball, H. J., Mansour, H., Mitchell, A., Maluish, L. and Hunt, N. H. (2006). Perforin mediated apoptosis of cerebral microvascular 
endothelial cells during experimental cerebral malaria. International Fournal for Parasitology 36, 485-496.

Rae, C., Mcquillan, J. A., Parekh, S. B., Bubb, W. A., Weiser, S., Balcar, V. J., Hansen, A. M., Ball, H. J. and Hunt, N. H. (2004). Brain gene expression, metabolism, and bioenergetics: interrelationships in murine models of cerebral and noncerebral malaria. FASEB Fournal 18, 499-510.

Randall, L. M., Amante, F. H., Mcsweeney, K. A., Zhou, Y., Stanley, A. C., Haque, A., Jones, M. K., Hill, G. R., Boyle, G. M. and Engwerda, C. R. (2008a). Common strategies to prevent and modulate experimental cerebral malaria in mouse strains with different susceptibilities. Infection and Immunity 76, 3312-3320.

Randall, L. M., Amante, F. H., Zhou, Y., Stanley, A. C., Haque, A., Rivera, F., Pfeffer, K., Scheu, S., Hill, G. R., Tamada, K. and Engwerda, C. R. $(2008 b)$. Cutting edge: selective blockade of LIGHT-lymphotoxin beta receptor signaling protects mice from experimental cerebral malaria caused by Plasmodium berghei ANKA. Fournal of Immunology 181, 7458-7462.

Reader, J. C., Cowman, A. F., Davern, K. M., Beeson, J. G., Thompson, J. K., Rogerson, S. J. and Brown, G. V. (1999). The adhesion of Plasmodium falciparum-infected erythrocytes to chondroitin sulfate A is mediated by $P$. falciparum erythrocyte membrane protein 1. Proceedings of the National Academy of Sciences, USA 90, 5198-5202.

Renia, L., Potter, S. M., Mauduit, M., Rosa, D. S., Kayibanda, M., Deschemin, J. C., Snounou, G. and Gruner, A. C. (2006). Pathogenic T cells in cerebral malaria. International Fournal for Parasitology 36, 547-554.

Rest, J. R. (1982). Cerebral malaria in inbred mice. I. A new model and its pathology. Transactions of the Royal Society of Tropical Medicine and Hygiene 76, 410-415.

Rogerson, S. J., Tembenu, R., Dobano, C., Plitt, S., Taylor, T. E. and Molyneux, M. E. (1999). Cytoadherence characteristics of Plasmodium falciparum-infected erythrocytes from Malawian children with severe and uncomplicated malaria. American Fournal of Tropical Medicine and Hygiene 61, 467-472.

Rudin, W., Eugster, H. P., Bordmann, G., Bonato, J., Muller, M., Yamage, M. and Ryffel, B. (1997).

Resistance to cerebral malaria in tumor necrosis factor-alpha/beta-deficient mice is associated with a reduction of intercellular adhesion molecule-1 up-regulation and T helper type 1 response. American Fournal of Pathology 150, 257-266.

Saeftel, M., Krueger, A., Arriens, S., Heussler, V., Racz, P., Fleischer, B., Brombacher, F. and Hoerauf, A. (2004). Mice deficient in interleukin-4 (IL-4) or IL-4 receptor alpha have higher resistance to sporozoite infection with Plasmodium berghei (ANKA) than do naive wild-type mice. Infection and Immunity 72, 322-331.

Salanti, A., Dahlback, M., Turner, L., Nielsen, M. A., Barfod, L., Magistrado, P., Jensen, A. T., Lavstsen, T., Ofori, M. F., Marsh, K., Hviid, L. and Theander, T. G. (2004). Evidence for the involvement of VAR2CSA in pregnancy-associated malaria. Yournal of Experimental Medicine 200, 1197-1203.

Schaeffer, M., Han, S. J., Chtanova, T., Van Dooren, G. G., Herzmark, P., Chen, Y., Roysam, B., Striepen, B. and Robey, E. A. (2009). Dynamic imaging of T cell-parasite interactions in the brains of mice chronically infected with Toxoplasma gondii. Fournal of Immunology 182, 6379-6393.

Scherf, A., Lopez-Rubio, J. J. and Riviere, L. (2008). Antigenic variation in Plasmodium falciparum. Anпиаl Review of Microbiology 62, 445-470.

Schluesener, H. J., Kremsner, P. G. and Meyermann, R. (1998). Widespread expression of MRP8 and MRP14 in human cerebral malaria by microglial cells. Acta Neuropathologica 96, 575-580.

Schofield, L. and Grau, G. E. (2005). Immunological processes in malaria pathogenesis. Nature Reviews Immunology 5, 722-735.

Schofield, L., Novakovic, S., Gerold, P., Schwarz, R. T., McConville, M. J. A and Tachado, S. D. (1996). Glycosylphosphatidylinositol toxin of Plasmodium up-regulates intercellular adhesion molecule-1, vascular cell adhesion molecule-1, and E-selectin expression in vascular endothelial cells and increases leukocyte and parasite cytoadherence via tyrosine kinase-dependent signal transduction. Fournal of Immunology 156, 1886-1896.

Seydel, K. B., Milner, D. A. Jr., Kamiza, S. B., Molyneux, M. E. and Taylor, T. E. (2006). The distribution and intensity of parasite sequestration in Comatose Malawian Children. Fournal of Infectious Diseases 194, 205-208.

Silamut, K., Phu, N. H., Whitty, C., Turner, G. D., Louwrier, K., Mai, N. T., Simpson, J. A., Hien, T. T. and White, N. J. (1999). A quantitative analysis of the microvascular sequestration of malaria parasites in the human brain. American Fournal of Pathology 155, 395-410.

Smith, J. D., Craig, A. G., Kriek, N., Hudson-Taylor, D., Kyes, S., Fagan, T., Pinches, R., Baruch, D. I., Newbold, C. I. and Miller, L. H. (2000).

Identification of a Plasmodium falciparum intercellular adhesion molecule-1 binding domain: a parasite adhesion trait implicated in cerebral malaria. Proceedings of the National Academy of Sciences, USA 97, 1766-1771.

Srivastava, K., Cockburn, I. A., Swaim, A., Thompson, L. E., Tripathi, A., Fletcher, C. A., Shirk, E. M., Sun, H., Kowalska, M. A., Fox-Talbot, K., Sullivan, D., Zavala, F. and Morrell, C. N. (2008). Platelet factor 4 mediates inflammation in experimental cerebral malaria. Cell Host $\Theta^{\circ}$ Microbe 4, 179-187.

Taylor, T. E., Fu, W. J., Carr, R. A., Whitten, R. O., Mueller, J. S., Fosiko, N. G., Lewallen, S., Liomba, N. G. and Molyneux, M. E. (2004). Differentiating the pathologies of cerebral malaria by postmortem parasite counts. Nature Medicine 10, 143-145.

Teasdale, G. and Jennett, B. (1974). Assessment of coma and impaired consciousness. A practical scale. Lancet 2, 81-84.

Togbe, D., De Sousa, P. L., Fauconnier, M., Boissay, V., Fick, L., Scheu, S., Pfeffer, K., Menard, R., 
Grau, G. E., Doan, B. T., Beloeil, J. C., Renia, L., Hansen, A. M., Ball, H. J., Hunt, N. H., Ryffel, B. and Quesniaux, V. F. (2008). Both functional LTbeta receptor and TNF receptor 2 are required for the development of experimental cerebral malaria. PLoS One 3, e2608.

Tripathi, A. K., Sha, W., Shulaev, V., Stins, M. F. and Sullivan, D. J., Jr. (2009). Plasmodium falciparum infected erythrocytes induce $\mathrm{NF}-\{$ kappa $\} \mathrm{B}$ regulated inflammatory pathways in human cerebral endothelium. Blood 114, 4234-4252.

Turner, G. D., Morrison, H., Jones, M., Davis, T. M., Looareesuwan, S., Buley, I. D., Gatter, K. C., Newbold, C. I., Pukritayakamee, S., Nagachinta, B. and $\boldsymbol{e t} \boldsymbol{a l}$. (1994). An immunohistochemical study of the pathology of fatal malaria. Evidence for widespread endothelial activation and a potential role for intercellular adhesion molecule-1 in cerebral sequestration. American Fournal of Pathology 145, 1057-1069.

Udomsangpetch, R., Pipitaporn, B., Silamut, K., Pinches, R., Kyes, S., Looareesuwan, S., Newbold, C. and White, N. J. (2002). Febrile temperatures induce cytoadherence of ring-stage Plasmodium falciparum-infected erythrocytes. Proceedings of the National Academy of Sciences, USA 99, 11825-11829.

Udomsangpetch, R., Reinhardt, P. H., Schollaardt, T., Elliott, J. F., Kubes, P. and Ho, M. (1997). Promiscuity of clinical Plasmodium falciparum isolates for multiple adhesion molecules under flow conditions. Fournal of Immunology 158, 4358-4364.

Udomsangpetch, R., Taylor, B. J., Looareesuwan, S., White, N. J., Elliott, J. F. and Ho, M. (1996). Receptor specificity of clinical Plasmodium falciparum isolates: nonadherence to cell-bound E-selectin and vascular cell adhesion molecule-1. Blood 88, 2754-2760.

Van Den Steen, P. E., Deroost, K., Van Aelst, I., Geurts, N., Martens, E., Struyf, S., Nie, C. Q., Hansen, D. S., Matthys, P., Van Damme, J. and Opdenakker, G. (2008). CXCR3 determines strain susceptibility to murine cerebral malaria by mediating T lymphocyte migration toward IFN-gamma-induced chemokines. European Fournal of Immunology 38, 1082-1095.

Van Der Heyde, H. C., Nolan, J., Combes, V., Gramaglia, I. and Grau, G. E. (2006). A unified hypothesis for the genesis of cerebral malaria: sequestration, inflammation and hemostasis leading to microcirculatory dysfunction. Trends in Parasitology 22, 503-508.

Van Hensbroek, M. B., Palmer, A., Onyiorah, E., Schneider, G., Jaffar, S., Dolan, G., Memming, H., Frenkel, J., Enwere, G., Bennett, S., Kwiatkowski, D. and Greenwood, B. (1996). The effect of a monoclonal antibody to tumor necrosis factor on survival from childhood cerebral malaria. Fournal of Infectious Diseases 174, 1091-1097.

Verra, F., Mangano, V. D. and Modiano, D. (2009). Genetics of susceptibility to Plasmodium falciparum: from classical malaria resistance genes towards genome-wide association studies. Parasite Immunology 31, 234-253.

Von Zur Muhlen, C., Sibson, N. R., Peter, K., Campbell, S. J., Wilainam, P., Grau, G. E., Bode, C.,
Choudhury, R. P. and Anthony, D. C. (2008). A contrast agent recognizing activated platelets reveals murine cerebral malaria pathology undetectable by conventional MRI. The Fournal of Clinical Investigation 118, 1198-1207.

Walther, M., Jeffries, D., Finney, O. C., Njie, M., Ebonyi, A., Deininger, S., Lawrence, E., NgwaAmambua, A., Jayasooriya, S., Cheeseman, I. H., Gomez-Escobar, N., Okebe, J., Conway, D. J. and Riley, E. M. (2009). Distinct roles for FOXP3 and FOXP3 CD4 $\mathrm{T}$ cells in regulating cellular immunity to uncomplicated and severe Plasmodium falciparum malaria. PLoS Pathogens 5, e1000364.

Wassmer, S. C., Combes, V. and Grau, G. E. (2003). Pathophysiology of cerebral malaria: role of host cells in the modulation of cytoadhesion. Annals of the New York Academy of Science 992, 30-38.

Wassmer, S. C., De Souza, J. B., Frere, C., Candal, F. J., Juhan-Vague, I. and Grau, G. E. (2006). TGF-beta1 released from activated platelets can induce TNF-stimulated human brain endothelium apoptosis: a new mechanism for microvascular lesion during cerebral malaria. Fournal of Immunology 176, 1180-1184.

Wassmer, S. C., Lepolard, C., Traore, B., Pouvelle, B., Gysin, J. and Grau, G. E. (2004). Platelets reorient Plasmodium falciparum-infected erythrocyte cytoadhesion to activated endothelial cells. Fournal of Infectious Diseases 189, 180-189.

Weiser, S., Miu, J., Ball, H. J. and Hunt, N. H. (2007). Interferon-gamma synergises with tumour necrosis factor and lymphotoxin-alpha to enhance the mRNA and protein expression of adhesion molecules in mouse brain endothelial cells. Cytokine 37, 84-91.

White, V. A., Lewallen, S., Beare, N. A., Molyneux, M. E. and Taylor, T. E. (2009). Retinal pathology of pediatric cerebral malaria in Malawi. PLoS One 4, e4317.

Wilson, E. H., Harris, T. H., Mrass, P., John, B., Tait, E. D., Wu, G. F., Pepper, M., Wherry, E. J., Dzierzinski, F., Roos, D., Haydon, P. G., Laufer, T. M., Weninger, W. and Hunter, C. A. (2009). Behavior of parasite-specific effector CD8 $+\mathrm{T}$ cells in the brain and visualization of a kinesis-associated system of reticular fibers. Immunity 30, 300-311.

Yanez, D. M., Manning, D. D., Cooley, A. J., Weidanz, W. P. and Van Der Heyde, H. C. (1996). Participation of lymphocyte subpopulations in the pathogenesis of experimental murine cerebral malaria. Fournal of Immunology 157, 1620-1624.

Yeo, T. W., Lampah, D. A., Gitawati, R., Tjitra, E., Kenangalem, E., McNeil, Y. R., Darcy, C. J., Granger, D. L., Weinberg, J. B., Lopansri, B. K., Price, R. N., Duffull, S. B., Celermajer, D. S. and Anstey, N. M. (2007). Impaired nitric oxide bioavailability and L-arginine reversible endothelial dysfunction in adults with falciparum malaria. Fournal of Experimental Medicine 204, 2693-2704.

Yeo, T. W., Lampah, D. A., Gitawati, R., Tjitra, E., Kenangalem, E., McNeil, Y. R., Darcy, C. J., Granger, D. L., Weinberg, J. B., Lopansri, B. K., Price, R. N., Duffull, S. B., Celermajer, D. S. and Anstey, N. M. (2008). Recovery of endothelial function in severe falciparum malaria: relationship with 
improvement in plasma L-arginine and blood lactate concentrations. Fournal of Infectious Diseases 198, 602-608.

Yipp, B. G., Anand, S., Schollaardt, T., Patel, K. D., Looareesuwan, S. and Ho, M. (2000). Synergism of multiple adhesion molecules in mediating cytoadherence of Plasmodium falciparum-infected erythrocytes to microvascular endothelial cells under flow. Blood 96, 2292-2298.

Yoeli, M. and Hargreaves, B. J. (1974). Brain capillary blockage produced by a virulent strain of rodent malaria. Science 184, 572-573. 